University of Wollongong

Research Online

Faculty of Engineering and Information

Faculty of Engineering and Information

Sciences - Papers: Part B

Sciences

2017

\title{
Analytical model for vacuum consolidation incorporating soil disturbance caused by mandrel-driven drains
}

\author{
Darshana Perera \\ University of Wollongong, mdap398@uowmail.edu.au \\ Buddhima Indraratna \\ University of Wollongong, indra@uow.edu.au \\ Serge Leroueil \\ Universite Laval \\ Cholachat Rujikiatkamjorn \\ University of Wollongong, cholacha@uow.edu.au \\ Richard Kelly \\ SMEC
}

Follow this and additional works at: https://ro.uow.edu.au/eispapers1

Part of the Engineering Commons, and the Science and Technology Studies Commons

Research Online is the open access institutional repository for the University of Wollongong. For further information contact the UOW Library: research-pubs@uow.edu.au 


\title{
Analytical model for vacuum consolidation incorporating soil disturbance caused by mandrel-driven drains
}

\author{
Abstract \\ When vacuum preloading is applied with vertical drains, the rate of consolidation can be increased, and \\ the stability of an embankment is enhanced due to the inward lateral movement. The aim of this study is \\ to develop an analytical solution for vacuum preloading that accurately captures the more realistic \\ variations in compressibility and permeability in actual ground conditions as a result of drain installation. \\ The soil samples were obtained from various locations after drain installation to determine the \\ characteristics of soil surrounding the vertical drain in terms of compressibility and permeability. The \\ main differences between the proposed and conventional models are described by considering the stress \\ history and preloading pressure. The effect of pre-consolidation pressure and the magnitude of applied \\ preloading are examined through the dissipation of average excess pore pressure and associated \\ settlement. The analysis of a selected case history employing the writers' solution indicates improved \\ accuracy of the predictions in comparison to the field measurements.

\section{Disciplines} \\ Engineering | Science and Technology Studies

\section{Publication Details} \\ Perera, D., Indraratna, B., Leroueil, S., Rujikiatkamjorn, C. \& Kelly, R. (2017). Analytical model for vacuum \\ consolidation incorporating soil disturbance caused by mandrel-driven drains. Canadian Geotechnical \\ Journal, 54 (4), 547-560.
}




\title{
An analytical model for vacuum consolidation incorporating soil disturbance caused by mandrel-driven drains
}

\author{
Darshana Perera \\ $\mathrm{PhD}, \mathrm{BSc}$ (Hons.) \\ Centre for Geomechanics and Railway Engineering, \\ School of Civil Engineering, Faculty of Engineering, \\ University of Wollongong, Wollongong City, NSW 2522, Australia

\section{Buddhima Indraratna} \\ PhD (Alberta), MSc (Lond.), BSc (Hons., Lond.), DIC, FIEAust., FASCE, FGS \\ Distinguished Professor of Civil Engineering, Faculty of Engineering, \\ Director, Centre for Geomechanics and Railway Engineering; University of \\ Wollongong, Wollongong City, NSW 2522, Australia
}

\section{Serge Leroueil}

$\mathrm{PhD}$, ing.

Professor, Department of Civil Engineering, Laval University, Quebec, Canada

\section{Cholachat Rujikiatkamjorn}

BEng (Hons), MEng (AIT), PhD

Associate Professor, Centre for Geomechanics and Railway Engineering,

School of Civil Engineering, Faculty of Engineering,

University of Wollongong, Wollongong City, NSW 2522, Australia

\section{Richard Kelly}

$\mathrm{BE}, \mathrm{PhD}$

Chief Technical Principal: Geotechnical, SMEC, Australia

Author for correspondence:

Prof. B. Indraratna

Faculty of Engineering

University of Wollongong

Wollongong, NSW 2522, Australia.

Ph: +61242213046

Fax: +61 242213238

Email: indra@uow.edu.au 


\section{An analytical model for vacuum consolidation incorporating soil disturbance caused by mandrel-driven drains}

Darshana Perera, Buddhima Indraratna, Cholachat Rujikiatkamjorn, Richard Kelly and Serge Leroueil

Abstract:

When vacuum preloading is applied with vertical drains, the rate of consolidation can be increased, and the stability of an embankment is enhanced due to the inward lateral movement. The aim of this study is to develop an analytical solution for vacuum preloading which accurately captures the more realistic variations in compressibility and permeability in actual ground conditions as a result of drain installation. The soil samples were obtained from various locations after drain installation to determine the characteristics of soil surrounding the vertical drain in terms of compressibility and permeability. The main differences between the proposed and conventional models are described by considering the stress history and preloading pressure. The effect of pre-consolidation pressure and the magnitude of applied preloading are examined through the dissipation of average excess pore pressure and associated settlement. The analysis of a selected case history employing the writers' solution indicates improved accuracy of the predictions in comparison to the field measurements.

Keywords: smear zone, soil structure, vacuum preloading, prefabricated vertical drains. 


\section{Introduction}

A vacuum pressure in conjunction with prefabricated vertical drains (PVD) was introduced by Kjellman (1952) and since then has become a popular method of ground improvement all over the world (Shang et al 1998; Long et al., 2015). Indraratna et al. (2005a, 2005b) presented comprehensive analytical models for radial consolidation with vacuum preloading. When vertical drains are installed with a steel mandrel, a disturbed region known as the smear zone is created; this affects consolidation due to changes in lateral permeability and compressibility. Analytical models for radial consolidation such as those developed by Hansbo (1981) and Indraratna \& Redana (1997) assume a reduced permeability coefficient inside the smear zone, whereas lateral permeability within the smear zone changes from a minimum value at the drain to a maximum value (undisturbed) beyond the boundary of the smear zone. Walker \& Indraratna (2006) considered a more realistic linear variation of permeability within the smear zone and modified the analytical solution for radial drainage. Indraratna et al. (2005a) and Indraratna et al. (2005b) successfully extended the radial consolidation theory to incorporate vacuum preloading, however, a constant permeability within the smear zone was considered in the solution.

The main assumptions based on Barron (1948) and Hansbo (1981) theories are similar to the assumptions made in the Terzaghi consolidation theory, where a constant value for the coefficient of volume compressibility and lateral permeability are assumed during consolidation. However, as consolidation occurs the void ratio of the soil gradually decreases which causes the coefficient of volume compressibility and lateral permeability to vary (Tavenas et al., 1983). To obtain more accurate predictions of the pore pressure and ground settlement, the variation of 
compressibility and permeability must be considered in the analysis. Lekha et al. (2003) modified the Terzaghi consolidation equation to include the variations of compressibility and permeability, and then Indraratna et al. (2005c) incorporated this into their radial consolidation equation. However, the change in soil compressibility due to drain installation (Soil disturbance) was ignored.

Leroueil \& Vaughan, (1990) stated that natural soil has a distinct structure that would not be available in reconstituted clay samples. The installation of a rigid mandrel during drain installation alters the structure of the soil such that the compressibility and the lateral permeability are affected (Chai \& Miura, 1999). Most of the earlier laboratory studies carried out to investigate the smear effects were performed on large reconstituted samples of soil, and therefore the analytical solutions developed for radial consolidation only consider the variation of lateral permeability due to the effects of drain installation; the role played by compressibility was not captured properly in those solutions. After testing large scale undisturbed samples Rujikiatkamjorn et al. (2013) proposed a concept to incorporate the variations of compressibility and permeability as a function of effective stress and degree of disturbance, and then Rujikiatkamjorn \& Indraratna (2014) presented a follow up analytical model for radial consolidation. However, none of these analytical models developed for vacuum preloading could capture the soil-structure characteristics and corresponding changes of compressibility and permeability due to mandrel-driven drain installation.

In this paper, an analytical solution is revised to capture the effect of vacuum preloading incorporating variations of compressibility and permeability due to the destructuration of soil caused by drain installation. This solution assumes a linear variation of vacuum pressure along the length of the drain while the associated pore 
pressure distribution and settlement can be obtained for both normally consolidated and lightly over-consolidated clays. Inside the smear zone, the linear variation of permeability is assumed with a gradual increase to a maximum value of in-situ permeability at and beyond the boundary of the smear zone.

\section{Compression behaviour of structured clay subjected to disturbance due to drain installation}

Most deposits of natural clay were formed by sedimentation and subsequent one dimensional consolidation under its own weight over thousands of years. These deposits exhibit permeability and compressibility anisotropy due to factors such as the distinct soil structure, nature of deposition, effective overburden pressure, stress history, and the cementation bonds (Randolph \& Wroth, 1979). Natural soils are different from reconstituted soils due to the influence of macro and micro 'structures' inherent in natural soils (Burland, 1990; Leroueil \& Vaughan, 1990; Gens and Nova, 1993). Mitchell (1976) described this 'structure' as a combination of the arrangement of particles known as the fabric and the inter-particle bonds.

When vacuum preloading is used with vertical drains, a rigid steel mandrel is used to drive these slender drains into the soil, and this action results in a disturbed region around the drain that is known as the smear zone. In Figure 1 the compression curves represent the structured undisturbed soil beyond the smear zone that is subjected to very little or no disturbance due to drain installation, while the soil surrounding the drain is severely disturbed. Detailed mathematical formulations related to Figure 1 were originally presented by Liu \& Carter (1999) and later modified by Rujikiatkamjorn et al. (2013) and Rujikiatkamjorn \& Indraratna (2014). 
To assess the destructuration of soil due to mandrel installation, samples of undisturbed soil were extracted after drain installation and before the construction of an embankment built on the low-lying flood plains at Ballina, NSW, Australia (Indraratna et al., 2015). The characteristics of soil compressibility and permeability were determined via oedometer consolidation tests. Vertical and horizontal specimens were taken $50 \mathrm{~mm}-600 \mathrm{~mm}$ away from a vertical drain (Figure 2a). The experimental data were then fitted to the conceptual model described in Rujikiatkamjorn \& Indraratna (2014), and these plots are shown in Figure 2b. It can be seen that the yield stress of the undisturbed sample $\left(\sigma_{\mathrm{vy}(i, U)}^{\prime}-\right.$ See Figure 1) collected $600 \mathrm{~mm}$ away from the drain was $28 \mathrm{kPa}$, whereas the sample obtained 50 mm away had decreased to $17.6 \mathrm{kPa}$.

\section{Analytical model for radial consolidation considering vacuum pressure and soil structure characteristics}

Chu et al. (2000) observed in the field that the distribution of vacuum pressure along the depth of the drain was not uniform, and later Indraratna et al. (2005a) reported a loss of vacuum with the depth of drain in laboratory experiments with large scale samples. The presence of intermediate layers of thin sand in coastal areas and the resistance of relatively long wick drains may be attributed to the loss of vacuum, and therefore a linear variation of vacuum pressure was assumed in this analysis; the axisymmetric unit cell and vacuum pressure distribution is shown in Figure 3. 
The main assumptions made in the Authors' analysis are summarised below:

- $\quad$ The soil is fully saturated and homogeneous, and Darcy's law is adopted. At the drain influence zone flow is not permitted, and for relatively long drains, only horizontal flow is allowed.

- $\quad$ Based on the equal strain concept (Barron 1948), equal vertical strains at a depth $z$ are assumed.

- $\quad$ The variation of permeability in the smear zone is assumed to be linear, so during consolidation, the change of permeability in the unit cell with void ratio is assumed to be nonlinear

The average excess pore water pressure $\left(\bar{u}_{t}\right)$ at any time $t$ in the unit cell can be given as;

$$
\bar{u}_{t}=\frac{\partial \epsilon}{\partial t} \frac{R^{2} \mu}{2 k_{h}} \gamma_{w}-\frac{\left(1+k_{1}\right)}{2} p_{0}
$$

Where $\epsilon$ is the strain, $R$ is the radius of the influenced area of drain, $k_{h}$ is the horizontal permeability, $p_{0}$ is the vacuum pressure applied, and $k_{1}$ is the vacuum pressure reduction factor.

Ignoring the secondary terms, the value of $\mu$ can be simplified to:

$$
\mu=\ln \left(\frac{n}{s}\right)-\frac{3}{4}+\frac{\kappa(s-1)}{s-\kappa} \ln \left(\frac{s}{\kappa}\right)
$$

The detailed derivation of Equation 1 is given in Appendix A.

Excess pore water pressure ratio $\left(R_{u}\right)$ can be defined as, 


$$
R_{u}=\frac{\bar{u}_{t}}{\Delta \sigma^{\prime}}
$$

In an over-consolidated state $\bar{\sigma}^{\prime} \leq \bar{\sigma}^{\prime}$ and $\mathrm{t} \leq t_{i}$, Equation 1 can be combined with Equation 3 to give:

$$
R_{u}=\frac{\partial \bar{e}}{\partial \bar{\sigma}^{\prime}} \frac{\partial\left(\sigma-\bar{u}_{t}\right)}{\partial t} \frac{d_{e}^{2} \mu}{8 k_{h}\left(1+\bar{e}_{0}\right) \Delta \sigma^{\prime}} \gamma_{w}-\frac{\left(1+k_{1}\right)}{2} \frac{p_{0}}{\Delta \sigma^{\prime}}
$$

where $d_{e}=2 R$ is the diameter of the influence zone, and $t_{i}$ is the time required for soil to change from an over-consolidated state to a normally-consolidated state.

In a normally consolidated state $\left(\bar{\sigma}^{\prime}>\bar{\sigma}^{\prime}{ }_{y}\right.$ and $\left.\mathrm{t}>t_{i}\right)$ the average initial void ratio can be taken as $\bar{e}_{i}$, and the excess pore water ratio can be expressed as:

$$
R_{u}=\frac{\partial \bar{e}}{\partial \bar{\sigma}^{\prime}} \frac{\partial\left(\sigma-\bar{u}_{t}\right)}{\partial t} \frac{d_{e}^{2} \mu}{8 k_{h}\left(1+\bar{e}_{i}\right) \Delta \sigma^{\prime}} \gamma_{w}-\frac{\left(1+k_{1}\right)}{2} \frac{p_{0}}{\Delta \sigma^{\prime}}
$$

A surcharge load and vacuum preloading are applied instantaneously to the top of the unit cell, and it was assumed that these loads do not vary with time. Therefore, the total stress applied was constant where the total stress $\left(\Delta \sigma^{\prime}\right)$ applied was equal to the surcharge load and the magnitude of vacuum pressure. Thus, rearranging Equation 4a gives:

$$
R_{u}=-\frac{\partial \bar{e}}{\partial \bar{\sigma}^{\prime}}\left(\frac{\partial \bar{u}_{t}}{\partial t} \frac{1}{\Delta \sigma^{\prime}}\right) \frac{d_{e}^{2} \mu}{8 k_{h}\left(1+\bar{e}_{0}\right)} \gamma_{w}-\frac{\left(1+k_{1}\right)}{2} \frac{p_{0}}{\Delta \sigma^{\prime}}
$$

and,

$$
\frac{\partial R_{u}}{\partial T_{h o}}=-\frac{8}{\mu} P\left(R_{u}+\frac{\left(1+k_{1}\right)}{2} \frac{p_{0}}{\Delta \sigma^{\prime}}\right)
$$

Refer to Appendix B for the derivation of Equation 6. Function $P$ is defined by, 


$$
\begin{array}{ll}
P=\left(1+\frac{u_{0}}{\sigma_{0}^{\prime}}-\frac{R_{u} \Delta \sigma^{\prime}}{\sigma_{0}^{\prime}}\right)^{1-\left({ }^{c_{s}} / c_{k}\right)} & \bar{\sigma}^{\prime} \leq \bar{\sigma}_{y}^{\prime} \\
P=\left(\frac{\sigma_{0}^{\prime}}{\bar{\sigma}_{y}^{\prime}}+\frac{u_{0}}{\bar{\sigma}_{y}^{\prime}}-\frac{R_{u} \Delta \sigma^{\prime}}{\bar{\sigma}_{y}^{\prime}}\right)^{1-\left(\bar{c}_{c} / c_{k}\right)} & \bar{\sigma}^{\prime}>\bar{\sigma}_{y}^{\prime}
\end{array}
$$

To simplify the above nonlinear finite difference equation, the value of $P$ is taken as the average of these separate regions, and is given by (details of derivation are in Appendix B);

$$
\begin{array}{ll}
P=P_{a v, 0}=0.5\left[\left(\frac{\bar{\sigma}_{y}^{\prime}}{\sigma_{0}^{\prime}}\right)^{1-\left(c_{s} / c_{k}\right)}+1\right] & \bar{\sigma}^{\prime} \leq \bar{\sigma}_{y}^{\prime} \\
P=P_{a v, i}=0.5\left[\left(\frac{\sigma_{0}^{\prime}+\Delta \sigma^{\prime}}{\bar{\sigma}_{y}^{\prime}}\right)^{1-\left(\bar{c}_{c} / c_{k}\right)}+1\right] & \bar{\sigma}^{\prime}>\bar{\sigma}_{y}^{\prime}
\end{array}
$$

Equation 6 can be rearranged as,

$$
\frac{\partial R_{u}}{\partial T_{h}^{*}}=-\frac{8}{\mu}\left(R_{u}+\frac{\left(1+k_{1}\right)}{2} \frac{p_{0}}{\Delta \sigma^{\prime}}\right)
$$

$T_{h}^{*}$ is defined as,

$$
\begin{array}{ll}
T_{h 0}^{*}=P_{a v, 0} T_{h 0}=0.5\left[\left(\frac{\bar{\sigma}_{y}^{\prime}}{\sigma_{0}^{\prime}}\right)^{1-\left(c_{s} / c_{k}\right)}+1\right] T_{h 0} & \bar{\sigma}^{\prime} \leq \bar{\sigma}_{y}^{\prime} \\
T_{h i}^{*}=P_{a v, i} T_{h i}=0.5\left[\left(\frac{\sigma_{0}^{\prime}+\Delta \sigma^{\prime}}{\bar{\sigma}_{y}^{\prime}}\right)^{1-\left(\bar{c}_{c} / c_{k}\right)}+1\right] T_{h i} & \bar{\sigma}^{\prime}>\bar{\sigma}_{y}^{\prime}
\end{array}
$$


Integrating Equation 8 in an over-consolidated state $\bar{\sigma}^{\prime} \leq \bar{\sigma}_{y}^{\prime}$ and $\mathrm{t} \leq t_{i}$ and in a normally consolidated state $\overline{\sigma^{\prime}}>\bar{\sigma}_{y}^{\prime}$ and $\mathrm{t}>t_{i}$, the values of $R_{u}$ can be derived as follows:

$$
\begin{aligned}
& R_{u}=\left[\begin{array}{cc}
\left(\frac{u_{0}}{\Delta \sigma^{\prime}}+\frac{\left(1+k_{1}\right)}{2} \frac{p_{0}}{\Delta \sigma^{\prime}}\right) \times \\
\exp \left\{-\left[\left(\frac{\bar{\sigma}_{y}^{\prime}}{\sigma_{0}^{\prime}}\right)^{1-\left(c_{s} / c_{k}\right)}+1\right] \frac{4 T_{h 0}}{\mu}\right\} \\
-\frac{\left(1+k_{1}\right)}{2} \frac{p_{0}}{\Delta \sigma^{\prime}}
\end{array}\right] \quad \overline{\bar{\sigma}^{\prime} \leq \bar{\sigma}_{y}^{\prime}} \\
& R_{u}=\left[\begin{array}{cc}
\left(\frac{\left(\sigma_{0}^{\prime}+u_{0}-\bar{\sigma}_{y}^{\prime}\right)}{\Delta \sigma^{\prime}}+\frac{\left(1+k_{1}\right)}{2} \frac{p_{0}}{\Delta \sigma^{\prime}}\right) \times \\
\exp \left\{-\left[\left(\frac{\sigma_{0}^{\prime}+\Delta \sigma^{\prime}}{\bar{\sigma}_{y}^{\prime}}\right)^{1-\left(\bar{c}_{c} / c_{k}\right)}+1\right] \frac{4 T_{h i}}{\mu}\right\} \\
-\frac{\left(1+k_{1}\right)}{2} \frac{p_{0}}{\Delta \sigma^{\prime}}
\end{array}\right] \quad \overline{\bar{\sigma}^{\prime}>\bar{\sigma}_{y}^{\prime}}
\end{aligned}
$$

$t_{i}$ can be obtained from Equation 10 by substituting $R_{u}=\left(\sigma_{0}^{\prime}+u_{0}-\bar{\sigma}_{y}^{\prime}\right) /_{\Delta \sigma^{\prime}}$

$$
t_{i}=\frac{\mu d_{e}^{2}}{4 c_{h o}\left[\left(\frac{\bar{\sigma}_{y}^{\prime}}{\sigma_{0}^{\prime}}\right)^{1-\left(c^{c_{s}} / c_{k}\right)}+1\right]} \ln \left(\frac{u_{0}+\frac{\left(1+k_{1}\right)}{2} p_{0}}{\sigma_{0}^{\prime}+u_{0}-\bar{\sigma}_{y}^{\prime}+\frac{\left(1+k_{1}\right)}{2} p_{0}}\right)
$$

In a vacuum preloading project the degree of consolidation can be measured from the excess pore water pressure as well as the settlement data. An expression to evaluate 
the average degree of consolidation $\left(U_{p}\right)$ using the pore pressure distribution profiles can be written as,

$$
\begin{gathered}
U_{p}=1-\frac{\int\left[u_{t}(z)-u_{s}(z)\right] d z}{\int\left[u_{0}(z)-u_{s}(z)\right] d z} \\
u_{s}(z)=\gamma_{w} z-p_{0}(z)
\end{gathered}
$$

where $u_{0}(z)$ is the initial pore water pressure, $z$ is the depth of the soil layer, $u_{t}(z)$ is a pore water pressure at depth $z$ at any given time, $u_{s}(z)$ represents the minimum pore pressure that can be expected when a vacumm pressure is applied, and $p_{0}(z)$ is the vacuum pressure applied. Equation 12 can be simplified to include $R_{u}$ as,

$$
U_{p}=1-\left(R_{u}+\frac{p_{0}}{\Delta \sigma^{\prime}}\right)
$$

Rujikiatkamjorn and Indraratna (2014) stated that if the surcharge fill is assumed to be a ramp loading, the excess pore pressure ratio during ramp loading $\left(R_{u}^{*}\right)$ can be taken as,

$$
R_{u}^{*}=\frac{\Delta \sigma_{t}^{\prime}}{\Delta \sigma^{\prime}} R_{u}
$$

where $\Delta \sigma_{t}^{\prime}$ is the applied surcharge load at time $t$ during ramp loading and $\Delta \sigma^{\prime}$ is the final surcharge load.

The average degree of consolidation based on settlement $\left(U_{s}\right)$ can then be given by;

$$
U_{s}=\frac{\rho}{\rho_{\infty}}
$$


where $\rho$ is the settlement at any given time and $\rho_{\infty}$ is the ultimate settlement.

\section{Determining the soil parameters}

\subsection{Average void ratio and compressibility parameters}

As shown in Figure 2, the compression curves vary according to the distance from the drain as the degree of disturbance decreases. The initial average void ratio and the yield stress (the pre-consolidation pressure) are required to determine the ultimate settlement for the entire unit cell, so it is better to use the average compression curve to simulate the behaviour of soil cylinder around a vertical drain after the smear zone is created. The average void ratio and yield stress can be calculated using the approach explained by Rujikiatkamjorn \& Indraratna (2014) (See Figure 5). The void ratio along the average compression curve can be described by the following equations,

$$
\begin{aligned}
& \bar{e}=\bar{e}_{0}-c_{S} \log \left(\frac{{\overline{\sigma^{\prime}}}_{\sigma_{0}^{\prime}}}{\sigma^{\prime}} \quad{\overline{\sigma^{\prime}}}^{\prime} \bar{\sigma}_{y}^{\prime}\right. \\
& \bar{e}=\bar{e}_{0}-c_{s} \log \left(\frac{\bar{\sigma}_{y}^{\prime}}{{\sigma_{0}^{\prime}}_{0}}\right)-\bar{c}_{c} \log \left(\frac{{\overline{\sigma^{\prime}}}_{\bar{\sigma}_{y}^{\prime}}}{\bar{\sigma}^{\prime}} \quad{\overline{\sigma^{\prime}}}^{\prime} \bar{\sigma}_{y}^{\prime}\right.
\end{aligned}
$$

where $\bar{c}_{c}$ is the average compression index for a given stress range in a normally consolidated region, and $c_{s}$ is the recompression index in the overconsolidation region. It is noted that the average recompression index $\left(c_{s}\right)$ is the same as the recompression index of the undisturbed curve, $\bar{e}$ is the average void ratio at any average vertical effective pressure $\bar{\sigma}^{\prime}, \bar{e}_{0}$ is the average void ratio at the initial stage at an effective vertical stress of ${\sigma^{\prime}}_{0}$, and $\bar{e}_{f}$ is the average void ratio at the final effective stress $\sigma_{f}^{\prime}$. The pre-consolidation stress (yield stress) of the 
average curve is denoted by ${\overline{\sigma^{\prime}}}_{y}$. The average void ratio of the initial stage and the final stage can be given as follows,

$$
\begin{gathered}
\bar{e}_{0}=\frac{e_{i, U}}{(n-1)}\left(\frac{1}{f_{0}}\left[\frac{\left(f_{0}+1\right)(s-1)}{2}\right]+(n-s)\right) \\
f_{0}=\frac{e_{i, U}}{e\left(r_{w}\right) 0} \\
\bar{e}_{f}=\frac{e_{i, f}}{(n-1)}\left(\frac{1}{f_{f}}\left[\frac{\left(f_{f}+1\right)(s-1)}{2}\right]+(n-s)\right) \\
f_{f}=\frac{e_{f, U}}{e\left(r_{w}\right) f} \\
f_{i}=\frac{e_{i, U}}{e\left(r_{w}\right) i} \\
n=\frac{R}{r_{w}} ; s=\frac{r_{s}}{r_{w}}
\end{gathered}
$$

In the above equations, $e_{i, U}, e\left(r_{w}\right) 0, e_{i, f}, e_{f, U}, e\left(r_{w}\right) f, e_{i, U}$ and $e\left(r_{w}\right) i$ are explained in Figure 1.

Figure 4a shows the average compression curves for the undisturbed region and soil near the vertical drain for the data considered in this analysis. The average initial void ratio, yield stress, and the corresponding void ratio at the corresponding yield stress are $2.10,22.0 \mathrm{kPa}$ and 1.98 , respectively.

\subsection{Distribution of Permeability in the smear zone}

In previous radial consolidation models with vacuum pressure, a constant but reduced permeability was often assumed, but as laboratory observations confirm, a linear distribution of permeability within the smear zone proposed by Walker \& 
Indraratna (2007) has been incorporated in this analysis. The variations in permeability and the void ratio along the radius of the unit cell are shown in Figure 5.

According to Tavenas et al. (1983) the void ratio can be related to permeability as,

$$
e=e_{0}+c_{k} \log \left(\frac{k_{h}}{k_{h 0}}\right)
$$

where $c_{k}$ is the permeability index. The semi-log permeability vs void ratio relationship is shown in Figure $4 \mathrm{~b}$ with a slope $\left(c_{k}\right)$ of 0.84 . Even though the variation in permeability within the smear zone is taken as linear, the change of

$2 \mathrm{~h}$ permeability with void ratio within the unit cell during consolidation is a non-linear relationship; it was also assumed that the value of $c_{k}$ is not affected by drain installation.

\section{Parametric analysis}

\subsection{Effects of pre consolidation pressure and load increment ratio}

A sensitivity analysis has been performed to demonstrate how the model responds to varying model parameters in comparison with previously developed models. The model performance with varying load increment ratios was studied for normally consolidated and lightly over-consolidated clay. It was assumed that drains were installed in a square pattern with a spacing of $1.2 \mathrm{~m}$ and these drains were $100 \mathrm{~mm}$ wide and $3 \mathrm{~mm}$ thick. The drain parameters adopted from Indraratna et al. (2015) are listed in Table 1, and the soil parameters used in the analysis are tabulated in Table 2. The analytical models by Hansbo (1981) and Indraratna et al. (2005a) were used to compare with the performance of the current model. Samples of normally consolidated clay were loaded with an initial stress of $28 \mathrm{kPa}$ to a final stress of $68 \mathrm{kPa}$ for Case $\mathrm{A} ; 108 \mathrm{kPa}$ in Case $\mathrm{B}$; and $148 \mathrm{kPa}$ in Case $\mathrm{C}$; this 
corresponds to load increment ratios of 2.4, 3.9, and 5.3, respectively. At each loading step, $50 \%$ of the total stress was applied using vacuum preloading. Figure $6 \mathrm{a}$ shows the corresponding compression curves for (i) disturbed soil in the vicinity of the drain, (ii) an undisturbed sample beyond the smear zone, and (iii) the averaged compression curve between (i) and (ii) to represent the unit cell. According to Figure $6 \mathrm{~b}$, the proposed model gives less settlement. This is expected because in the models by Indraratna et al. (2005a) and Hansbo (1981), a virgin compression curve of the undisturbed region was used to calculate settlement, whereas in the current model a more realistic average compression curve is used to capture soil disturbance due to drain installation. The rate of settlement of the current model is less than the others. Figure $6 \mathrm{c}$ shows that the degree of consolidation in the current model is less than that of the other models at any given time.

The proposed model was simulated for lightly over-consolidated clay and the corresponding soil parameters used in the analysis are shown in Table 3. The drain parameters are the same as those used in the simulation of normally consolidated clay (See Table 1). Given the initial stress of the soil to be $10 \mathrm{kPa}$, Cases D, E, and F have been analysed with a final effective stress of $50 \mathrm{kPa}, 90 \mathrm{kPa}$, and $130 \mathrm{kPa}$, resulting in load increment ratios of 5.0, 9.0, and 13.0, respectively. The consolidation responses are shown in Figure 7. In Figure $7 \mathrm{a}$, three relevant compression curves are shown for the undisturbed, smeared soil beside the drain, and an averaged curve representing the influence of drain installation in the unit cell, in which the preconsolidation pressure is decreased from $28 \mathrm{kPa}$ to $17 \mathrm{kPa}$. The preconsolidation pressure is expected to decrease when a mandrel is inserted into the ground because it breaks the soil structure. 
A sensitivity analysis is conducted to study how the consolidation behaviour changes due to the (a) variation of permeability (b) variation of compressibility and (c) reduction of pre-consolidation pressure during soil disturbance caused by mandrel driving. Figure $7 \mathrm{~b}$ shows how settlement in the proposed model varies with time compared to Indraratna et al. (2005a) and Hansbo (1981), while the degree of consolidation with time is shown at the bottom of Figure 7c. In lightly overconsolidated soils the geological pre -consolidation pressure and compressibility decrease due to the destructuring of clay by mandrel intrusion. This reduction in preconsolidation pressure $\left(\sigma_{y}^{\prime}\right)$ will increase the total settlement, while a decrease in the compression index $\left(c_{c}\right)$ causes the settlement to decrease. The final vertical consolidation settlement calculated using the proposed method will depend on whether $\sigma_{y}^{\prime}$ and $c_{c}$ incorporate soil disturbance. Figure $7 \mathrm{~b}$ shows that for the lower load increment ratios the proposed model yields more settlement than Indraratna et al. (2005a). This is because as the load increment ratio increases, the latter tends to produce slightly larger settlement. Moreover, the settlement curve using the proposed model plots below the other curves in the lower range of load incremental ratios, but falls above or at the same value as the load increment ratio increases. Figure $7 \mathrm{c}$ also shows that the degree of consolidation in an over-consolidated state (where, $\sigma^{\prime} \leq \bar{\sigma}_{y}^{\prime}$ ) is similar for all the consolidation curves; case $\mathrm{F}$ with the highest stress ratio would yield first, followed by a slight reduction in the rate of consolidation. The other two cases are still in the recompression region, and with a higher coefficient of consolidation they consolidate faster than Case F. However, after about 200 days, all the cases are at a normally consolidated stage, albeit the degree of consolidation in Case F is higher than the other two cases. 
In the degree of consolidation curves obtained from the proposed method there is a 'kink' in all three cases considered, that are close to time $t_{i}$ (Equation 11) in Figure 7c. This aspect has been discussed in detail by Leroueil et al (1980 \& 1983). Rujikiatkamjorn \& Indraratna (2014) explain that this is due to a change in the compressibility index from $c_{S}$ to $\bar{c}_{c}$ at the pre-consolidation pressure. The abrupt change in curves by Indraratna et al (2005) and Hansbo (1981) cannot be seen because the models do not consider the change of compression curves at the preconsolidation pressure.

\subsection{Effects of vacuum loss}

When longer vertical drains are used and a vacuum pressure is applied, the total pressure applied by the vacuum pumps may not propagate to the tip of the drain. The factor of vacuum pressure transferred to the bottom of the drain is represented in the model by parameter $k_{1}$ (Figure 3 ). The presence of layers of permeable sand and higher horizontal stresses present in deeper layers of clay may explain the loss of vacuum, but when vacuum pressure is lost during consolidation the effective stress would decrease and hence reduce final settlement.

Figures 8 and 9 show how the vacuum pressure distributed along the depth of the drain affects the normally consolidated and over-consolidated clay. The soil parameters and drain characteristics, and loading conditions used in this analysis are identical to the values used in Case B and Case E in the proposed model simulation described earlier. Here, the pressure increment is $80 \mathrm{kPa}$, with half of it being vacuum pressure. The vacuum pressure distributions considered in the simulation are rectangular, $\left(k_{1}=1.0\right)$, triangular $\left(k_{1}=0\right)$, and trapezoidal, where $k_{1}=$ $0.25,0.50$ and $k_{1}=0.75$. 
Figures $8 \mathrm{a}$ and $9 \mathrm{a}$ show how the pore pressure varies with time for different levels of vacuum loss. As expected, a greater loss of vacuum would create a less effective stress increment in the soil. Figures $8 \mathrm{~b}$ and $9 \mathrm{~b}$ show how the settlement changes over time with different vacuum pressure distributions, and they clearly indicate that the greater the loss in VP, the lesser the resulting settlement.

\section{An application to a case study}

Preloading the embankment using a surcharge load and vacuum pressure with vertical drains was used to improve the soft soil site at Ballina, Australia. It allowed for rapid embankment construction and was more economical than the other methods (Kelly and Wong, 2009). According to Kelly et al. (2008), the soil underlying the trial embankment consisted of uniform layers of soft to firm estuarine and alluvial clays above residual soils and bedrock. The clay under the vacuum preloading embankment was almost 25 metres thick. The basic soil parameters used in the analysis were reported in Indraratna et al. (2012) and the average thickness of clay layers are given in Table 4. The area below Settlement plates SP1 and SP2 was treated with a surcharge load only, while the other sections were improved with a combination of surcharge load and vacuum pressure. The drain properties and other parameters required in the model are summarised in Table 5 (Extracted from Indraratna et al 2012), and the extent of the smear zone was taken as 6 times the equivalent diameter of the mandrel, as per the study conducted earlier by Indraratna et al. (2015).

The consolidation settlements and excess pore water pressures were estimated using the proposed method and then compared with the observed field data and the results obtained from previously developed analytical models by Indraratna et al. 
(2005a) and Hansbo (1981). Using the proposed model, Figure 10 shows the calculated settlements at settlement plates SP 4, 8, 10 and 12, which were then compared with the measured field data. The soil parameters in each layer that were used for the analysis at SP12 are tabulated in Table 6 and the thicknesses of the compressible layers under the relevant settlement plates are given in Table 4. An acceptable match between the predicted and measured settlement values was obtained, especially when the clay was very thick. Even though the total settlement of SP4, SP8 and SP10 matched well at 375 days, the predicted settlement rates during earlier consolidation stages were underestimated, possibly due to (a) an increase in vertical drainage encountered in shallow clay layers closer to the soil surface, and (b) the random presence of thin sand lenses in this coastal soil.

Figure 11 compares the settlement obtained using the proposed methods and the predictions of Indraratna et al. (2005a) and Hansbo (1981), for settlement recorded at SP12. The vacuum pumps were switched on after 102 days, and this point is marked as Point $\mathrm{A}$ in Figure 11. The final construction stage of the embankment ( $8.5 \mathrm{~m}$ high) commenced 17 days after the vacuum pumps were switched on, and even though they were switched off at point $\mathrm{C}$, the computations were continued by assuming that the total effective stress available after Point B remained unchanged. This was in order to compare the ultimate settlements using all three methods. These hypothetical curves are shown in Figure 11 after 378 days (Point C). It is seen that the settlements calculated from the analytical solutions developed by Indraratna et al. (2005a) and Hansbo (1981) are larger than the current analytical solution. This is because, in the past models proposed by Indraratna et al. (2005a) and Hansbo (1981), a virgin compression curve of the undisturbed region was used to determine the settlement, whereas in the current (authors') model, an 
average compression curve capturing soil disturbance attributed to drain installation was adopted.

Note that the proposed method agrees well with the field data compared to the other methods, and this proves the relevance of capturing the role of soil disturbance by mandrel action. The permeability and compressibility within the smear zone are overestimated in the past methods, and this leads to higher ultimate settlements and rates of consolidation.

Figure 12 shows the variations in excess pore water pressure recorded over time, as seen at $\mathrm{P} 2(\mathrm{P} 2 \mathrm{a}$ at $-8.3 \mathrm{~m}$ and $\mathrm{P} 2 \mathrm{~b}$ at $-4.8 \mathrm{~m})$, as well as the predictions based on the proposed model by Indraratna et al. (2005a) and Hansbo (1981). The final section of the embankment was raised within 107 days causing the pore water pressure to attain a maximum value that subsequently begins to dissipate with time. The excess pore water pressure observed in the field after 100 days is compared with the current simulation. Past models of Indraratna et al. (2005) and Hansbo (1981) indicate less excess pore water pressure compared to the proposed model that shows a closer agreement with the measured values. However, all the theoretical models predict a higher rate of pore water pressure dissipation at the end of embankment construction, unlike the actual measurements.

\section{Difference between destructuration and smear}

The parametric study and the case study analysis indicate that incorporating soil destructuration during drain installation leads to more realistic prediction of consolidation behaviour in a natural clay. To further investigate the impacts of smear and destructuration, another analysis has been performed. Basic soil properties used in Case D are adopted in the following models. 
Model A - Idealised model: Hansbo (1981) model is simulated with no smear and destructuration.

Model B - Smear: Hansbo (1981) is used with smear but no soil destructuration is considered.

Model C - Destructuration: No Smear: The current model is simulated by incorporating soil destructuration, but the smear effects were omitted in the analysis.

The results of this simulation are shown in Figure 13. As expected, by incorporating smear into an idealised model, a realistic rate of consolidation can be obtained, but the ultimate settlement will not be affected by the smear effect. Even though smear reduces the horizontal permeability it has no influence over the ultimate settlement. However, if the excess pore water pressure generated during drain installation (Sathananthan et al. 2008) is significant, then the total settlement will increase slightly due to the dissipation of that excess pore water pressure. This is not considered in this analysis.

When the effect of soil destructuration is incorporated (Model C), the actual ultimate settlement can be obtained, but it will depend on the amount of destructuration and the stress range chosen in the simulation, as described in Section 5.1. Since the smear effect is ignored, the rate of consolidation increases more than in Model B, although this rate is less than the idealised case. This proves that the current model can accurately simulate the compressibility and permeability characteristics of a soil improved with vertical drains and vacuum preloading.

\section{Conclusion}

In this study an analytical solution for radial consolidation with vertical drains and vacuum preloading that incorporates the effects of soil disturbance due to 
mandrel driven PVD installation has been developed. While the previous models included the effect of smear, the actual soil destructuration has not been captured properly. In this study, the average compression curve was used to represent a partially disturbed smear zone and the intact region beyond it, and the variations in permeability and compressibility with the void ratio were also considered in this analytical model.

The effects of soil disturbance due to drain installation were studied using samples obtained beneath an embankment constructed along the Pacific Highway at Ballina. The analytical model was used to obtain the degree of consolidation and variation in settlement over time, and the results were compared with Indraratna et al. (2005) and Hansbo (1981) in a parametric study. This comparison revealed that the current model can be used with either normally or lightly over-consolidated soils. It was noted that previous models overestimated the settlement and degree of consolidation compared to the proposed model.

Different vacuum pressure distributions could occur due to the loss of vacuum pressure, and this would create different pore pressure distributions and settlement values. The proposed model can simulate different vacuum pressure distributions with depth and also predict the reduced effective stress and associated total settlement with vacuum loss. This model was validated using a case study which had more realistic consolidation responses captured by previous approaches.

\section{Acknowledgement}

This research has been funded under the Australian Research Council (ARC) Linkage scheme. The first Author's PhD was sponsored through the Endeavour Scholarship scheme by the Australian government. The authors wish to acknowledge the support of the industry partners, namely the National Jute Board of India, Menard-Bachy, Coffey Geotechnics, Douglas Partners, and Soilwicks Pty Ltd. 


\section{APPENDIX A:}

The variation of vacuum pressure along the depth of the drain can be expressed as;

$$
p(z)=p_{0}\left[1-\left(1-k_{1}\right) \frac{Z}{l}\right]
$$

where $\mathrm{z}$ is the depth measured from the top of the surface, $p_{0}$ is the vacuum pressure applied from the top of the drain, and $k_{1}$ is the vacuum pressure reduction factor. An expression for the rate of discharge using Darcy's equation can be written as,

$$
\begin{aligned}
& \frac{\partial \mathrm{Q}}{\partial t}=k i A \\
& \frac{\partial \mathrm{Q}}{\partial t}=\frac{k_{h(r)}}{\gamma_{w}} \cdot \frac{\partial u}{\partial r} \cdot 2 \pi r d z
\end{aligned}
$$

$Q$ is the discharge through point x of a strip with a depth of $d z$ and $u$ is the excess pore water pressure. The rate of discharge through point $\mathrm{x}$ (Figure 3 ) is equal to the rate of change in the strain of soil volume beyond that point. Equal strain is assumed at the top of the unit cell.

$$
\frac{\partial Q}{\partial t}=\frac{\partial \epsilon}{\partial t} \cdot \pi\left(R^{2}-r^{2}\right) d z
$$

By A3 and A4,

$$
\frac{\partial u}{\partial r}=\frac{\partial \epsilon}{\partial t} \frac{\gamma_{w}}{2 k_{h(r)}} \frac{\left(R^{2}-r^{2}\right)}{r}
$$

where $\epsilon$ is the vertical strain, and $k_{h(r)}$ represents the variation of lateral permeability with the radius of the influence area of the drain $(R)$. Two expressions for the excess pore water pressure inside the smear zone and the undisturbed zone can be obtained as (See Figure 5): 


$$
\begin{aligned}
& k_{h}\left(r_{w}\right)=k\left(r_{w}\right)_{0} \\
& k_{h}\left(r_{s}\right)=k_{h}
\end{aligned}
$$

where, $r_{w}$ is the radius of the vertical drain and $r_{s}$ is the radius of the smear zone. The determination of equivalent vertical drain radius $\left(r_{w}\right)$ was based on $r_{w}=\frac{(a+b)}{4}$ proposed by Rixner et al. (1986) where $a$ and $b$ are the width and thickness of PVDs, respectively. Rixner et al. (1986) showed that the proposed method can provide an accurate representation of the band drain in the unit cell analysis. $k\left(r_{w}\right)_{0}$ is the horizontal permeability close to the drain (See Figure 5). Equation A8 will satisfy the boundary conditions of Equations A6 and A7, hence:

$$
\begin{gathered}
k_{h}=\frac{k_{h}}{\kappa}\left[\frac{C}{r_{w}} r+D\right] \quad r \leq r_{s} \\
C=\frac{\kappa-1}{s-1} \\
D=\frac{s-\kappa}{s-1} \\
\kappa=\frac{k_{h}}{k\left(r_{w}\right)_{0}} \\
k_{h}=k_{h} \\
s=\frac{r_{s}}{r_{w}}
\end{gathered}
$$

By applying the variation of permeability given in Equation A8 to Equation A5, two expressions for excess pore water pressure inside the smear zone and the undisturbed zone beyond it can be obtained. 
Within the smear zone $r_{w}<r \leq r_{s}$ assume the excess pore water pressure to be $u^{\prime}$

$$
\frac{\partial u^{\prime}}{\partial r}=\frac{\partial \epsilon}{\partial t} \frac{\gamma_{w}}{2\left\{\frac{k_{h}}{\kappa}\left[\frac{C}{r_{w}} r+D\right]\right\}} \frac{\left(R^{2}-r^{2}\right)}{r}
$$

Integrating Equation A9 w.r.t the radius $r$;

$$
u^{\prime}=\frac{\partial \epsilon}{\partial t} \frac{\gamma_{w} \kappa R^{2}}{2 k_{h}}\left[\begin{array}{c}
\left(\frac{D}{C^{2} n^{2}}-\frac{1}{D}\right) \ln \left(\frac{C r}{r_{w}}+D\right)+ \\
\frac{1}{D} \ln (r)-\frac{r}{C r_{w} n^{2}}
\end{array}\right]+c_{1}
$$

Applying the boundary condition, when $r=r_{w}, u=-p_{0}\left[1-\left(1-k_{1}\right) \frac{z}{l}\right]$ to the above Equation A10,

$$
u^{\prime}=\frac{\partial \epsilon}{\partial t} \frac{\gamma_{w} \kappa R^{2}}{2 k_{h}}\left[\begin{array}{c}
\left(\frac{D}{C^{2} n^{2}}-\frac{1}{D}\right) \ln \left(\frac{C r}{r_{w}}+D\right)+ \\
\frac{1}{D} \ln \left(\frac{r}{r_{w}}\right)-\frac{\left(r-r_{w}\right)}{C r_{w} n^{2}}
\end{array}\right]-p_{0}\left[1-\left(1-k_{1}\right) \frac{Z}{l}\right]
$$

Outside the smear zone $r_{s}<r \leq R$ expression for the excess pore water pressure $(u)$ can be written as;

$$
\frac{\partial u}{\partial r}=\frac{\partial \epsilon}{\partial t} \frac{\gamma_{w}}{2 k_{h}} \frac{\left(R^{2}-r^{2}\right)}{r}
$$

Integrating Equation A12 w.r.t the radius $r$; 


$$
u=\frac{\partial \epsilon}{\partial t} \frac{\gamma_{w} R^{2}}{2 k_{h}}\left[\frac{1}{r}-\frac{r}{R^{2}}\right]+c_{2}
$$

To obtain the pore pressure $\left(u_{s}\right)$ at the boundary of smear zone substitute $r=r_{s}$ in Equation A11,

$$
u_{s}=\frac{\partial \epsilon}{\partial t} \frac{\gamma_{w} \kappa R^{2}}{2 k_{h}}\left[\begin{array}{c}
\left(\frac{D}{C^{2} n^{2}}-\frac{1}{D}\right) \ln (\kappa)+ \\
\frac{1}{D} \ln (s)-\frac{(s-1)}{C n^{2}}
\end{array}\right]-p_{0}\left[1-\left(1-k_{1}\right) \frac{Z}{l}\right]
$$

Applying the above boundary condition $u_{s}=u_{\left(r=r_{s}\right)}$ to Equation A14, the excess pore pressure beyond the smear zone can be obtained as,

$$
u=\frac{\partial \epsilon}{\partial t} \frac{\gamma_{w} \kappa R^{2}}{2 k_{h}}\left[\begin{array}{c}
\ln \left(\frac{r}{r_{s}}\right)+\frac{1}{2 n^{2}}\left(s^{2}-\left\{\frac{r}{r_{w}}\right\}^{2}\right)+ \\
\kappa\left\{\begin{array}{c}
\left(\frac{D}{C^{2} n^{2}}-\frac{1}{D}\right) \ln (\kappa)+ \\
\frac{1}{D} \ln (s)-\frac{(s-1)}{C n^{2}}
\end{array}\right\}
\end{array}\right]-p_{0}\left[1-\left(1-k_{1}\right) \frac{Z}{l}\right]
$$

Excess pore pressure distribution within the smear zone and in the undisturbed zone beyond it is given in Equations A11 and A15. Expressions for the average pore pressure in the unit cell considered at any given time can be given as, 


$$
\begin{gathered}
\bar{u}_{t}=\frac{1}{\pi\left(R^{2}-r_{w}^{2}\right) l}\left[\int_{0}^{l} \int_{r_{w}}^{r_{s}} u^{\prime} 2 \pi r d r d z+\int_{0}^{l} \int_{r_{s}}^{R} u 2 \pi r d r d z\right] \\
\bar{u}_{t}=\frac{2}{\left(R^{2}-r_{w}^{2}\right) l}\left[\int_{0}^{l} \int_{r_{w}}^{r_{s}} u^{\prime} r d r d z+\int_{0}^{l} \int_{r_{s}}^{R} u r d r d z\right]
\end{gathered}
$$

Where $\bar{u}_{t}$ is the average excess pore pressure of the soil cylinder, at depth $z$, for vertical drain length $l$ and for a given time, $t$

Substituting the pore pressure expression in Equation A17 and integrating,

$$
\begin{gathered}
\bar{u}_{t}=\frac{\partial \epsilon}{\partial t} \frac{R^{2} \mu}{2 k_{h}} \gamma_{w}-\frac{\left(1+k_{1}\right)}{2} p_{0} \\
\mu=\frac{n^{2}}{n^{2}-1}\left[\begin{array}{l}
\left.\ln \left(\frac{n}{s}\right)-\frac{3}{4}+\frac{s^{2}}{n^{2}}\left(1-\frac{s^{2}}{4 n^{2}}\right)-\frac{\kappa}{B} \ln \left(\frac{\kappa}{s}\right)+\frac{\kappa B}{A^{2} n^{2}}\left(2-\frac{B^{2}}{A^{2} n^{2}}\right) \ln (\kappa)\right] \\
-\frac{\kappa(s-1)}{A n^{2}}\left(2+\frac{1}{n^{2}}\left(\frac{A-B}{A}\left(\frac{1}{A}-\frac{s+1}{2}\right)-\frac{(s+1)}{2}-\frac{(s-1)^{2}}{3}\right)\right)
\end{array}\right]
\end{gathered}
$$

After ignoring the secondary terms as $\mathrm{n}^{2}$ becomes large the value of $\mu$ can be simplified to:

$$
\mu=\ln \left(\frac{n}{s}\right)-\frac{3}{4}+\frac{\kappa(s-1)}{s-\kappa} \ln \left(\frac{s}{\kappa}\right)
$$

$2 \mathrm{a}$, Rujikiatkamjorn and Indraratna (2007) showed that when the ratio of length to the $2 d$ diameter of the drain influence zone is more than about 10 , the influence of vertical consolidation can be omitted. In this paper the effect of vertical consolidation is 
ignored, although vertical consolidation can be increasingly significant near the surface (say within a depth of 1-2m).

The mathematical expression for the average pore pressure in the unit cell at any given time at a depth $z\left(\bar{u}_{t}(z)\right)$ can be given by

$$
\bar{u}_{t}(z)=\frac{2}{\pi\left(R^{2}-r_{w}^{2}\right)}\left[\int_{r_{w}}^{r_{s}} u^{\prime} r d r+\int_{r_{s}}^{R} u^{\prime} r d r\right]
$$

In an over consolidated state $\overline{\sigma^{\prime}} \leq \bar{\sigma}_{y}^{\prime}$ and $\mathrm{t} \leq t_{i}$ and in a normally consolidated state $\overline{\sigma^{\prime}}>\bar{\sigma}_{y}^{\prime}$ and $\mathrm{t}>t_{i}$, the values of excess pore water pressure ratio $\left(R_{u}(z)=\frac{\bar{u}_{t}(z)}{\Delta \sigma^{\prime}}\right)$ at any time $\mathrm{t}$ at depth $\mathrm{z}$ can be derived as follows:

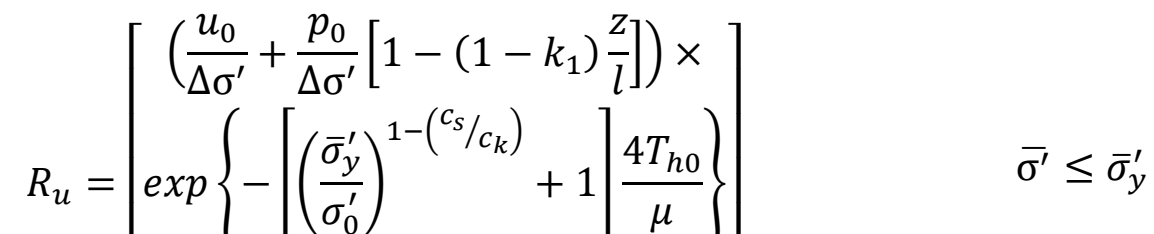

$$
\begin{aligned}
& {\left[-\frac{p_{0}}{\Delta \sigma^{\prime}}\left[1-\left(1-k_{1}\right) \frac{Z}{l}\right] \quad \mathrm{t} \leq t_{i}\right.} \\
& R_{u}=\left[\begin{array}{cc}
\left(\frac{\left(\sigma_{0}^{\prime}+u_{0}-\bar{\sigma}_{y}^{\prime}\right)}{\Delta \sigma^{\prime}}+\frac{p_{0}}{\Delta \sigma^{\prime}}\left[1-\left(1-k_{1}\right) \frac{z}{l}\right]\right) \times \\
\exp \left\{-\left[\left(\frac{\sigma_{0}^{\prime}+\Delta \sigma^{\prime}}{\bar{\sigma}_{y}^{\prime}}\right)^{1-\left(\bar{c}_{c} / c_{k}\right)}+1\right] \frac{4 T_{h i}}{\mu}\right\} \\
-\frac{p_{0}}{\Delta \sigma^{\prime}}\left[1-\left(1-k_{1}\right) \frac{z}{l}\right]
\end{array}\right] \quad{\overline{\sigma^{\prime}}>\bar{\sigma}_{y}^{\prime}}^{\mathrm{t}>t_{i}}
\end{aligned}
$$

$t_{i}$ can be obtained as: 


$$
t_{i}=\frac{\mu d_{e}^{2}}{4 c_{h o}\left[\left(\frac{\bar{\sigma}_{y}^{\prime}}{\sigma_{0}^{\prime}}\right)^{1-\left(c_{s} / c_{k}\right)}+1\right]} \ln \left(\frac{u_{0}+p_{0}\left[1-\left(1-k_{1}\right) \frac{Z}{l}\right]}{\sigma_{0}^{\prime}+u_{0}-\bar{\sigma}_{y}^{\prime}+p_{0}\left[1-\left(1-k_{1}\right) \frac{Z}{l}\right]}\right)
$$




\section{APPENDIX B}

$$
R_{u}=-\frac{\partial \bar{e}}{\partial \bar{\sigma}^{\prime}}\left(\frac{\partial \bar{u}_{t}}{\partial t} \frac{1}{\Delta \sigma^{\prime}}\right) \frac{d_{e}^{2} \mu}{8 k_{h}\left(1+\bar{e}_{0}\right)} \gamma_{w}-\frac{\left(1+k_{1}\right)}{2} \frac{p_{0}}{\Delta \sigma^{\prime}}
$$

Differentiating Equation 3,

$$
\frac{\partial R_{u}}{\partial t}=\frac{\partial \bar{u}_{t}}{\partial t} \frac{1}{\Delta \sigma^{\prime}}
$$

From Equations B1 and B2 and modifying further,

$$
\begin{gathered}
\frac{\partial R_{u}}{\partial t}=-\left(R_{u}+\frac{\left(1+k_{1}\right)}{2} \frac{p_{0}}{\Delta \sigma^{\prime}}\right)\left(\frac{\left(1+\bar{e}_{0}\right)}{\partial \bar{e} / \partial \overline{\sigma^{\prime}}}\right) \frac{8 k_{h}}{\mu d_{e}^{2} \gamma_{w}} \\
\frac{\partial R_{u}}{\partial t}=\frac{\partial R_{u}}{\partial T_{h 0}} \cdot \frac{\partial T_{h 0}}{\partial t} \\
\frac{T_{h o}}{d T_{h 0}}=\frac{c_{h o} t}{\partial t}=\frac{c_{h o}}{d_{e}^{2}} \\
c_{h o}=\frac{k_{h o}}{m_{v o} \gamma_{w}} \\
m_{v o}=\frac{\left(\partial \bar{e} / \partial \sigma_{\mathrm{v}}^{\prime}\right)_{t=0}}{\left(1+\bar{e}_{0}\right)}
\end{gathered}
$$

and,

$$
m_{v}=\frac{\partial \bar{e} / \partial \overline{\sigma^{\prime}}}{\left(1+\bar{e}_{0}\right)}
$$

Combining Equations B3 with B4, for $\overline{\sigma^{\prime}} \leq \bar{\sigma}_{y}^{\prime}$ gives;

$$
\frac{\partial R_{u}}{\partial T_{h o}}=-\frac{8}{\mu} \frac{m_{v o}}{m_{v}} \frac{k_{h}}{k_{h o}}\left(R_{u}+\frac{\left(1+k_{1}\right)}{2} \frac{p_{0}}{\Delta \sigma^{\prime}}\right)
$$

For over consolidated state (when $\bar{\sigma}^{\prime}>\bar{\sigma}_{y}^{\prime}$ ), a similar equation can be derived as; 


$$
\frac{\partial R_{u}}{\partial T_{h i}}=-\frac{8}{\mu} \frac{m_{v i}}{m_{v}} \frac{k_{h}}{k_{h i}}\left(R_{u}+\frac{\left(1+k_{1}\right)}{2} \frac{p_{0}}{\Delta \sigma^{\prime}}\right)
$$

where,

$$
\begin{aligned}
& T_{h i}=\frac{c_{h i}\left(t-t_{i}\right)}{d_{e}^{2}} \\
& c_{h i}=\frac{k_{h i}}{m_{v i} \gamma_{w}} \\
& m_{v i}=\frac{\left(\partial \bar{e} / \partial \sigma_{\mathrm{v}}^{\prime}\right)_{t=t_{i}}}{\left(1+\bar{e}_{i}\right)} \\
& m_{v}=\frac{\partial \bar{e} / \partial \sigma_{\mathrm{v}}^{\prime}}{\left(1+\bar{e}_{i}\right)}
\end{aligned}
$$

where $t_{i}$ is the time required for soil to change from an over-consolidated state into a normally-consolidated state. According to Indraratna et al. (2005a), the relationships between soil permeability, compressibility, and excess pore pressure can be expressed as:

$$
\begin{array}{ll}
\frac{k_{h}}{k_{h o}}=\left(1+\frac{u_{0}}{\sigma_{0}^{\prime}}-\frac{R_{u} \Delta \sigma^{\prime}}{\sigma_{0}^{\prime}}\right)^{-c_{s} / c_{k}}=\left(\frac{m_{v o}}{m_{v}}\right)^{-c_{s} / c_{k}} & \bar{\sigma}^{\prime} \leq \bar{\sigma}_{y}^{\prime} \\
\frac{k_{h}}{k_{h i}}=\left(\frac{\sigma_{o}^{\prime}}{\bar{\sigma}_{y}^{\prime}}+\frac{u_{0}}{\bar{\sigma}_{y}^{\prime}}-\frac{R_{u} \Delta \sigma^{\prime}}{\bar{\sigma}_{y}^{\prime}}\right)^{-\bar{c}_{c} / c_{k}}=\left(\frac{m_{v i}}{m_{v}}\right)^{-\bar{c}_{c} / c_{k}} & \bar{\sigma}^{\prime}>\bar{\sigma}_{y}^{\prime}
\end{array}
$$

By substituting Equation B7 to B5 the following can be obtained:

$$
\frac{\partial R_{u}}{\partial T_{h o}}=-\frac{8}{\mu} P\left(R_{u}+\frac{\left(1+k_{1}\right)}{2} \frac{p_{0}}{\Delta \sigma^{\prime}}\right)
$$

where function $P$ is defined by,

$$
P=\left(1+\frac{u_{0}}{\sigma_{0}^{\prime}}-\frac{R_{u} \Delta \sigma^{\prime}}{\sigma_{0}^{\prime}}\right)^{1-\left(c_{s} / c_{k}\right)} \quad \bar{\sigma}^{\prime} \leq \bar{\sigma}_{y}^{\prime}
$$




$$
P=\left(\frac{\sigma_{0}^{\prime}}{\bar{\sigma}_{y}^{\prime}}+\frac{u_{0}}{\bar{\sigma}_{y}^{\prime}}-\frac{R_{u} \Delta \sigma^{\prime}}{\bar{\sigma}_{y}^{\prime}}\right)^{1-\left(\bar{c}_{c} / c_{k}\right)} \quad \bar{\sigma}^{\prime}>\bar{\sigma}_{y}^{\prime}
$$

Equation B9 describes the radial consolidation of vertical drains with vacuum preloading under an instantaneous surcharge load and vacuum pressure, where the changes to compressibility and permeability due to drain installation are incorporated. However, this nonlinear finite difference equation does not have a

$2 \mathrm{~g} \quad$ general solution and the value $P$ varies with $R_{u}$. In the over consolidation region $R_{u}$ will vary from $u_{0} / \Delta \sigma^{\prime}$ to $\left(\sigma_{0}^{\prime}+u_{0}-\bar{\sigma}_{y}^{\prime}\right) / \Delta \sigma^{\prime}$ and in the normally consolidated region from $\left(\sigma_{0}^{\prime}+u_{0}-\bar{\sigma}_{y}^{\prime}\right) / \Delta \sigma^{\prime}$ to $-p_{0} / \Delta \sigma^{\prime}$. The value of $P$ is taken as the average of these separate regions and is given by;

$$
\begin{array}{ll}
P=P_{a v, 0}=0.5\left[\left(\frac{\bar{\sigma}_{i}^{\prime}}{\sigma_{0}^{\prime}}\right)^{1-\left(c_{s} / c_{k}\right)}+1\right] & \bar{\sigma}^{\prime} \leq \bar{\sigma}_{i}^{\prime} \\
P=P_{a v, i}=0.5\left[\left(\frac{\sigma_{0}^{\prime}+\Delta \sigma^{\prime}}{\bar{\sigma}_{i}^{\prime}}\right)^{1-\left(\bar{c}_{c} / c_{k}\right)}+1\right] & \bar{\sigma}^{\prime}>\bar{\sigma}_{i}^{\prime}
\end{array}
$$




\section{REFERENCES}

Barron, R. A. (1948). Consolidation of fine-grained soils by drain wells. Transactions ASCE, 113(2346),pp. 718-724.

Burland, J. B. (1990). On the compressibility and shear strength of natural clays. Géotechnique, 40,pp. 329-378.

Chai, J.-C. and Miura, N. (1999). Investigation of factors affecting vertical drain behavior. Journal of Geotechnical and Geoenvironmental Engineering, 125(23),pp. 216-226.

Chu, J., Yan, S. W. and Yang, H. (2000). Soil improvement by the vacuum preloading method for an oil storage station. Géotechnique, 50(6), pp. 625-632.

Gens, A., and Nova, R. (1993). Conceptual bases for a constitutive model for bonded soils and weak rocks. In Proceedings of the International Symposium under the Auspices of the International Society for Soil Mechanics and Foundation Engineering (ISSMFE). 20-23 September 1993. Part 1 (of 2). A.A. Balkema, Athens, Greece.

Hansbo, S. (1981). Consolidation of fine-grained soils by prefabricated drains. Proc. 10th Int. Conf. SMFE., 3, Stokholm,pp. 677-682.

Indraratna, B. and I. W. Redana (1997). Plane strain modeling of smear effects associated with vertical drains. J. Geotech. Eng., ASCE, 123(5),pp. 474-478.

Indraratna, B., Rujikiatkamjorn, C. and Sathananthan, I. (2005a). Analytical and numerical solutions for a single vertical drain including the effects of vacuum preloading. Canadian Geotechnical Journal, 42(4), pp. 994-1014. 
Indraratna, B., Sathananthan, I., Rujikiatkamjorn, C. and Balasubramaniam, A. S., (2005b). Analytical and numerical modeling of soft soil stabilized by prefabricated vertical drains incorporating vacuum preloading. International Journal of Geomechanics, 5(2), pp. 114-124.

Indraratna, B., Rujikiatkamjorn, C. and Sathananthan, I. (2005c). Radial consolidation of clay using compressibility indices and varying horizontal permeability. Canadian Geotechnical Journal, 42(5), pp. 1330-1341.

Indraratna, B., Rujikiatkamjorn, C., Kelly, R. and Buys, H., (2012). Soft soil foundation improved by vacuum and surcharge loading. Proceedings of the Institution of Civil Engineers: Ground Improvement, 165(2), pp. 87-96.

Indraratna, B., Perera, D., Rujikiatkamjorn, C. and Kelly, R. (2015) Soil disturbance analysis due to vertical drain installation. Proceedings of the Institution of the Civil Engineers: Geotechnical Engineering, 168(3), 236-246.

Kelly, R., Small, J. and Wong, P. (2008). Construction of an Embankment Using Vacuum Consolidation and Surcharge Fill. GeoCongress 2008,pp. 578-585.

Kelly, R. B. and Wong, P. K. (2009). An embankment constructed using vacuum consolidation. Australian Geomechanics, 44(2),pp. 55-64.

Kjellman, W. (1952). Consolidation of clayey soils by atmospheric pressure Proceedings of a conference on soil stabilization, Massachusetts Institute of Technology, Boston, pp. 258-263.

Lekha, K. R., Krishnaswamy, N. R. and Basak, P. (2003). Consolidation of clays for variable permeability and compressibility. Journal of Geotechnical and Geoenvironmental Engineering, ASCE, 129(11),pp. 1001-1009. 
Leroueil, S., Lebihan, J.P. and Tavenas, F (1980). An approach for the determination of the preconsolidation pressure in sensitive clays. Canadian Geotechnical Journal, 17, pp. 446-453.

Leroueil, S., Tavenas, F., Samson, L. and Morin, P., (1983). Preconsolidation pressure of Champlain clays: Part 2. Laboratory determination. Canadian Geotechnical Journal, 20, pp. 803-816.

Leroueil, S. and Vaughan, P. R. (1990). The general and congruent effects of structure in natural soils and weak rocks. Géotechnique, 40,pp. 467-488.

Liu, M. D. and Carter, J. P. (1999). Virgin compression of structured soils. Géotechnique, 49, pp. 43-57.

Long, P. V., Nguyen, L. V., Bergado, D. T., Balasubramaniam, A. S. (2015). Performance of PVD improved soft ground using vacuum consolidation methods with and without airtight membrane, Geotextiles and Geomembranes, 43(6), pp. 473-483.

Mitchell, J. K. (1976). Fundamentals of Soil Behavior. New York, Wiley. Total pages 577

Randolph, M. F. and Wroth, C. P. (1979). An analytical solution for the consolidation around a driven pile. International Journal for Numerical and Analytical Methods in Geomechanics, 3(3), pp. 217-229.

Rixner, J. J., Kraemer S. R. and Smith A. D. (1986). Prefabricated Vertical Drains, Vol. I, II and III: Summary of Research Report-Final Report. Washington D.C: 433

Rujikiatkamjorn, C., Ardana, M. D. W., Indraratna, B. and Leroueil, S. (2013). Conceptual model describing smear zone caused by mandrel action. 
Géotechnique, 63(16), pp. 1377-1388.Rujikiatkamjorn C. and Indraratna, B.

$2 \mathrm{a}$ (2007). Analytical solutions and design curves for vacuum-assisted consolidation with both vertical and horizontal drainage. Canadian Geotechnical J. Vol. 44, pp. 188-200.

Rujikiatkamjorn, C. and Indraratna, B. (2014). Analytical solution for radial consolidation considering soil structure characteristics. Canadian Geotechnical Journal, pp. 1-14.

Shang, J. Tang, Q., M. and Miao, Z. (1998). Vacuum preloading consolidation of reclaimed land: a case study. Canadian Geotechnical Journal, 35,pp. 740-749.

Tavenas, F., Leblond, P., Jean, P., and Leroueil, S. (1983). The permeability of natural soft clays, Part 2: Permeability characteristics. Canadian Geotechnical Journal, 20, pp. 645-660.

Walker, R. and Indraratna B. (2006). Vertical Drain Consolidation with Parabolic Distribution of Permeability in Smear Zone. Journal of Geotechnical and Geoenvironmental Engineering, 132(7), pp. 937-941. 


\section{FIGURES}

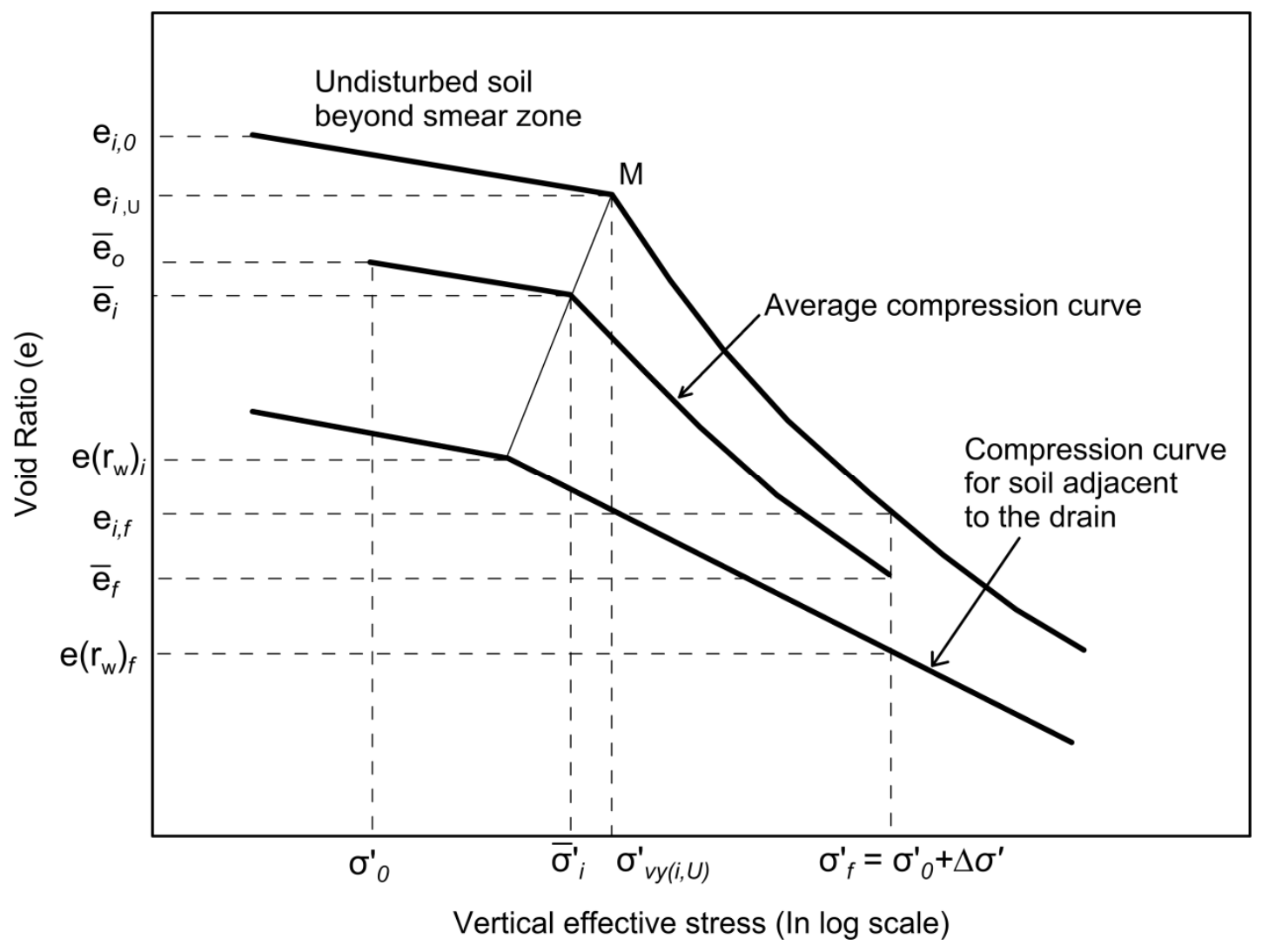

Figure 1 : Compression curves for in-situ and disturbed soil. 




Figure $2:$ a) Sampling locations and the b) Compression curves based on oedometer test 


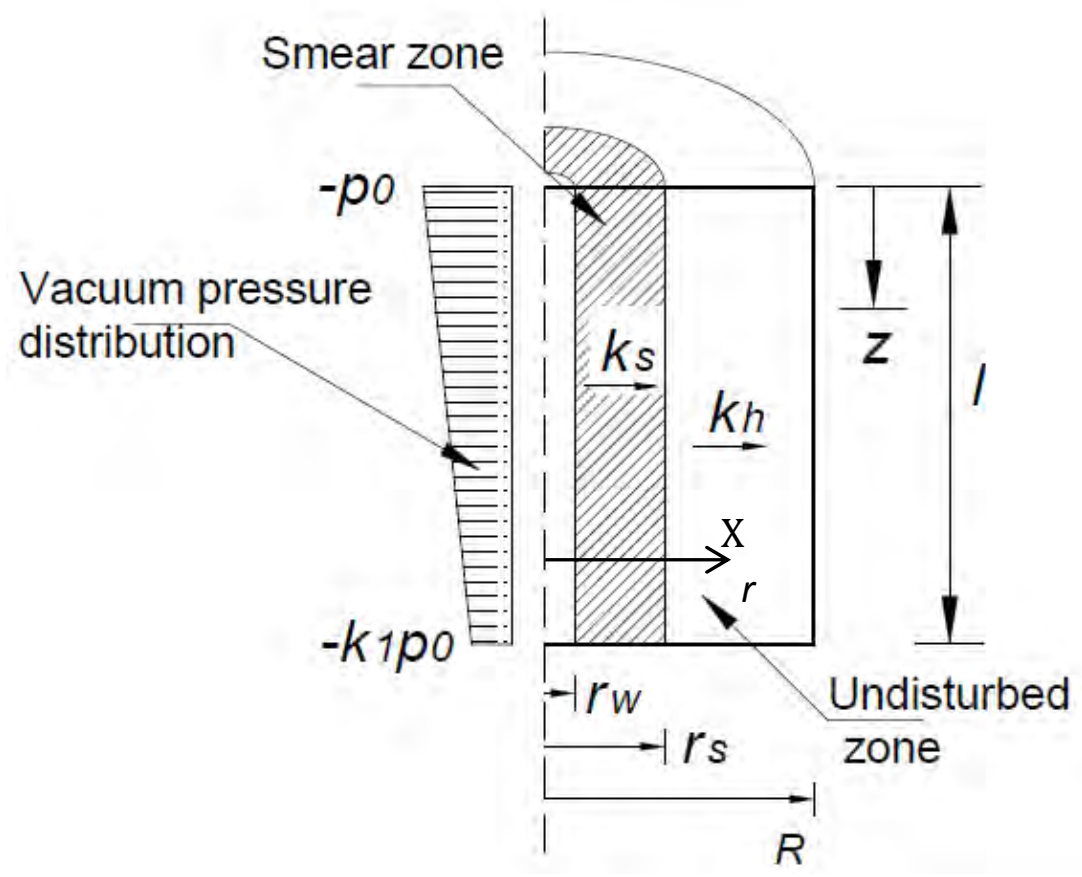

Figure 3: Vacuum pressure distribution in an axisymmetric unit cell 




Figure 4 : a) Averaged compression curves; b) Variation of permeability with the void ratio based on oedometer tests 

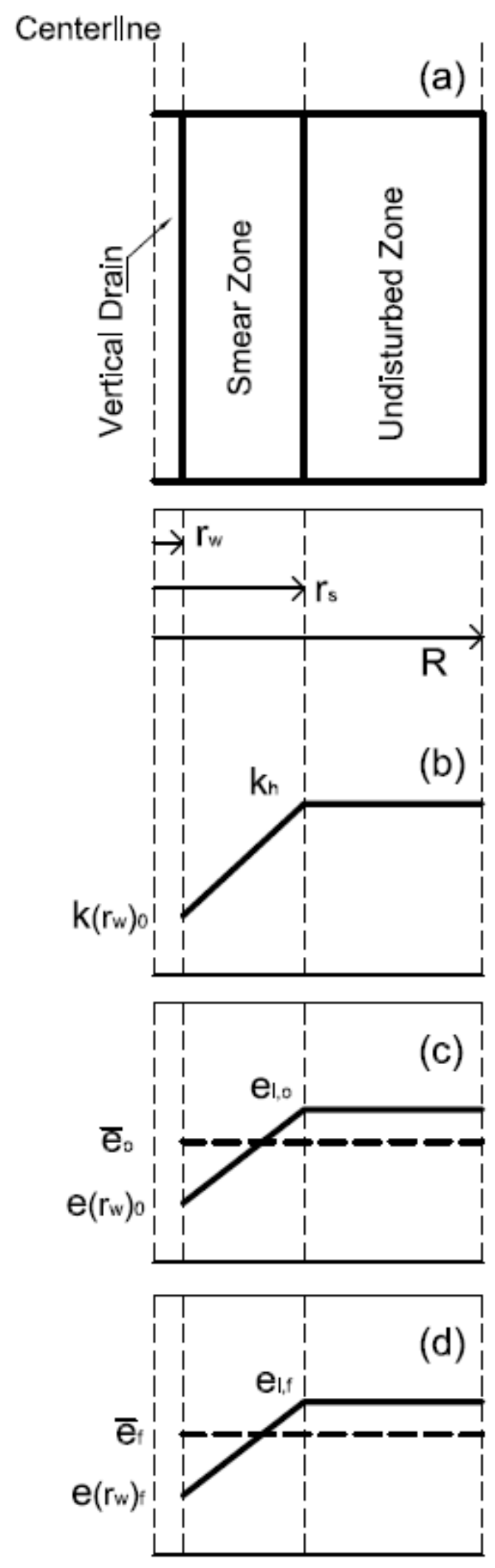

Figure 5 : Variation of b) Permeability; c) initial void ratio; d) final void ratio of a unit cell with a vertical drain (Modified after Rujikiatkamjorn \& Indraratna 2014) 

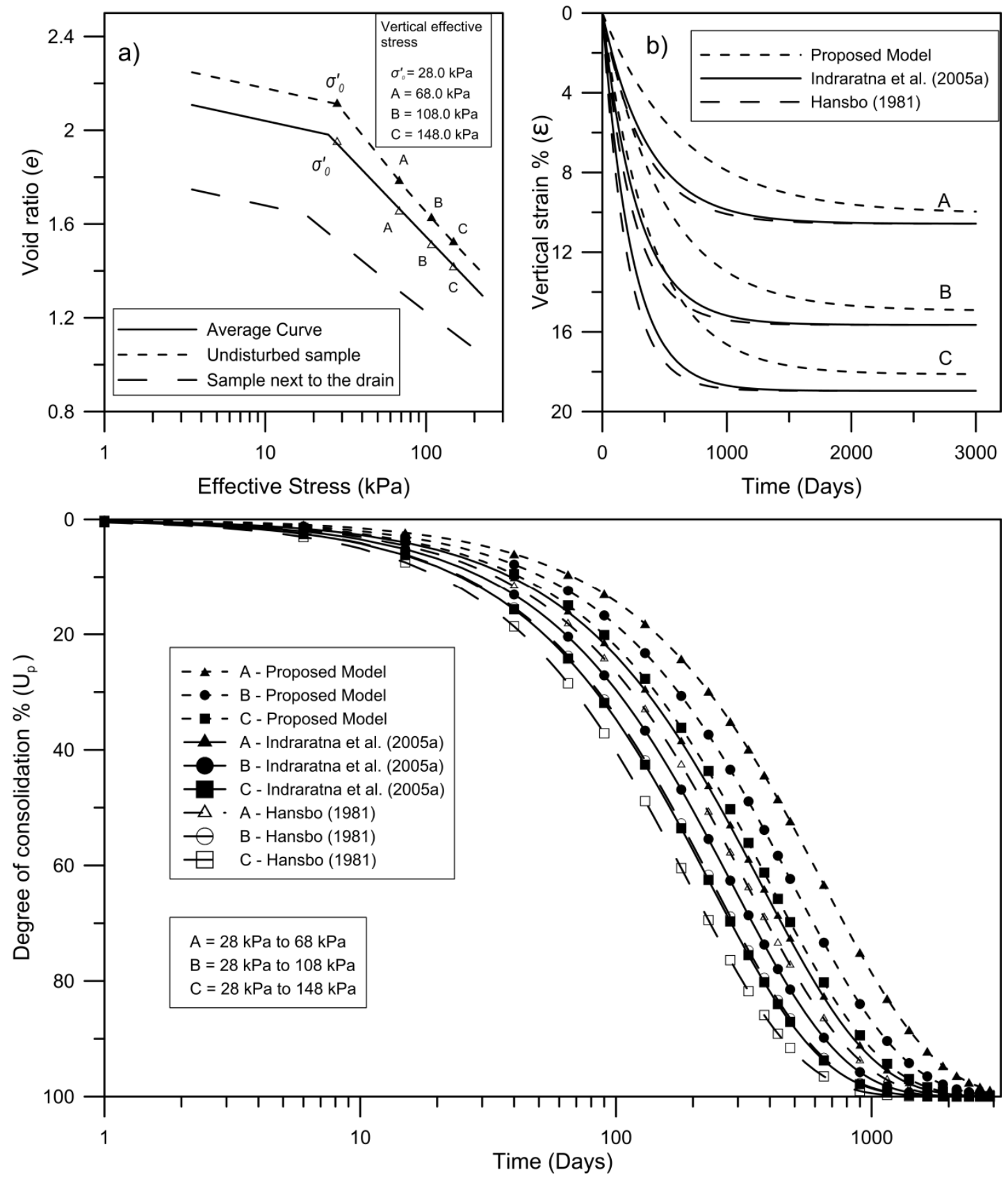

Figure 6 : Predicted model response of normally consolidated clay, compared to Indraratna et al. (2005a) and Hansbo (1981): (a) the relationship between the Void ratio and effective stress, and (b) vertical strain with time, and (c) the degree of consolidation with time 



Figure 7 : Consolidation of lightly over-consolidated clay by the predicted model compared to Indraratna et al. (2005a) and Hansbo (1981) showing: (a) the relationship between the Void ratio and effective stress, (b) the vertical strain with time, and (c) the degree of consolidation with time 


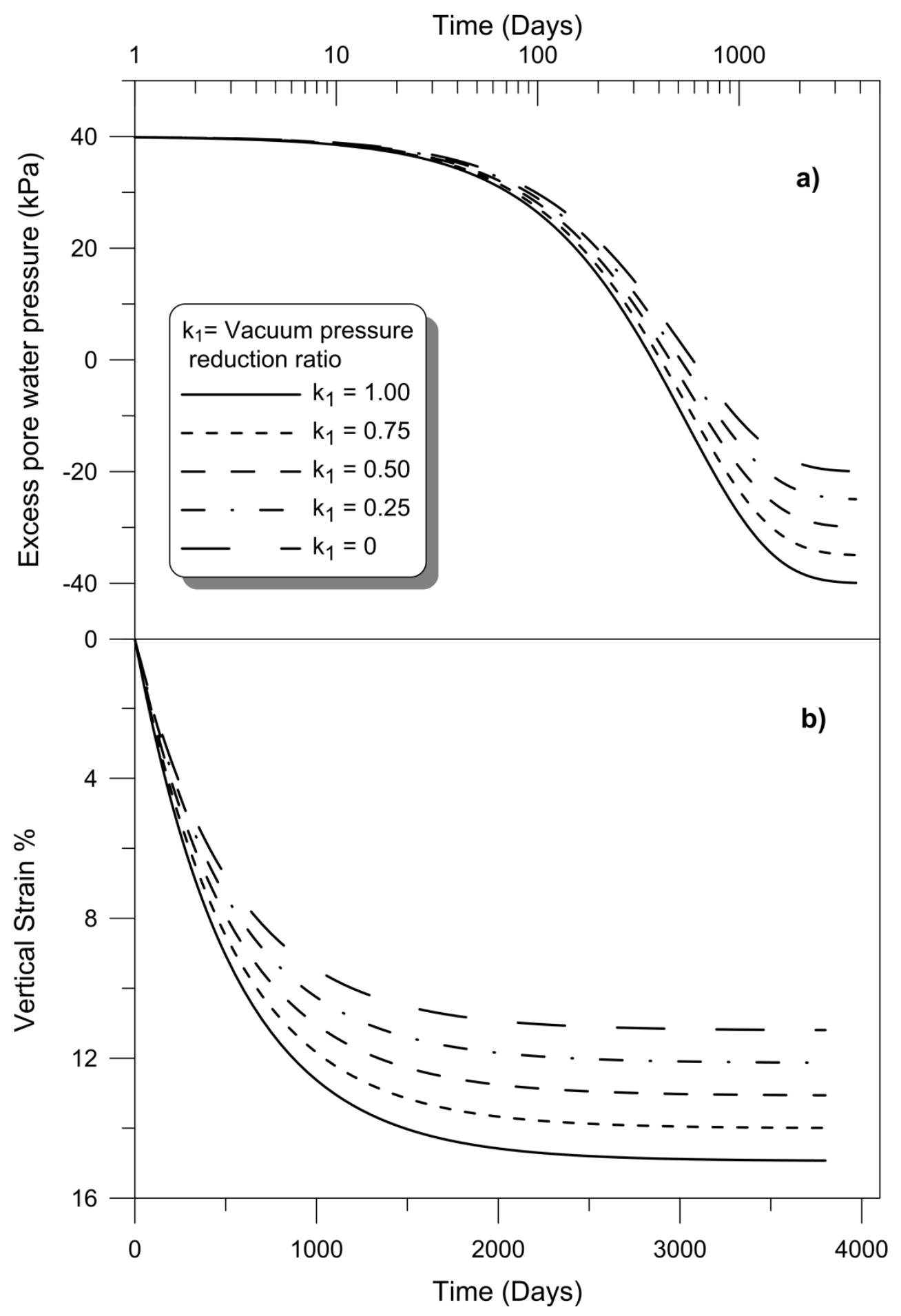

Figure 8 : Effects of vacuum distribution along the drain for normally consolidated clay: a) Excess pore water pressure; b) Vertical strain 


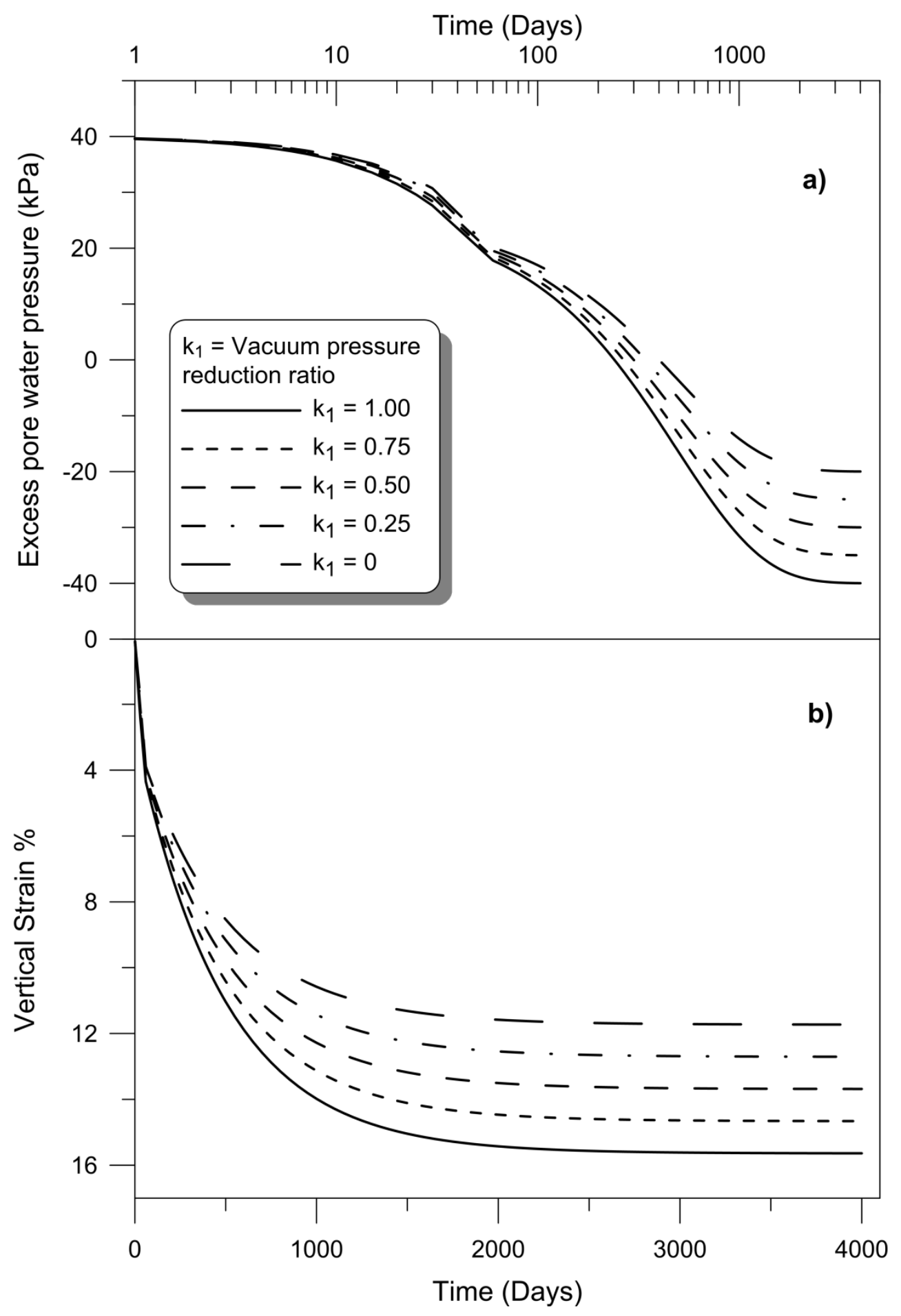

Figure 9 : Effects of vacuum distribution inside the drain on the consolidation parameters in lightly over consolidated clay: a) Excess pore water pressure; b) Vertical strain 


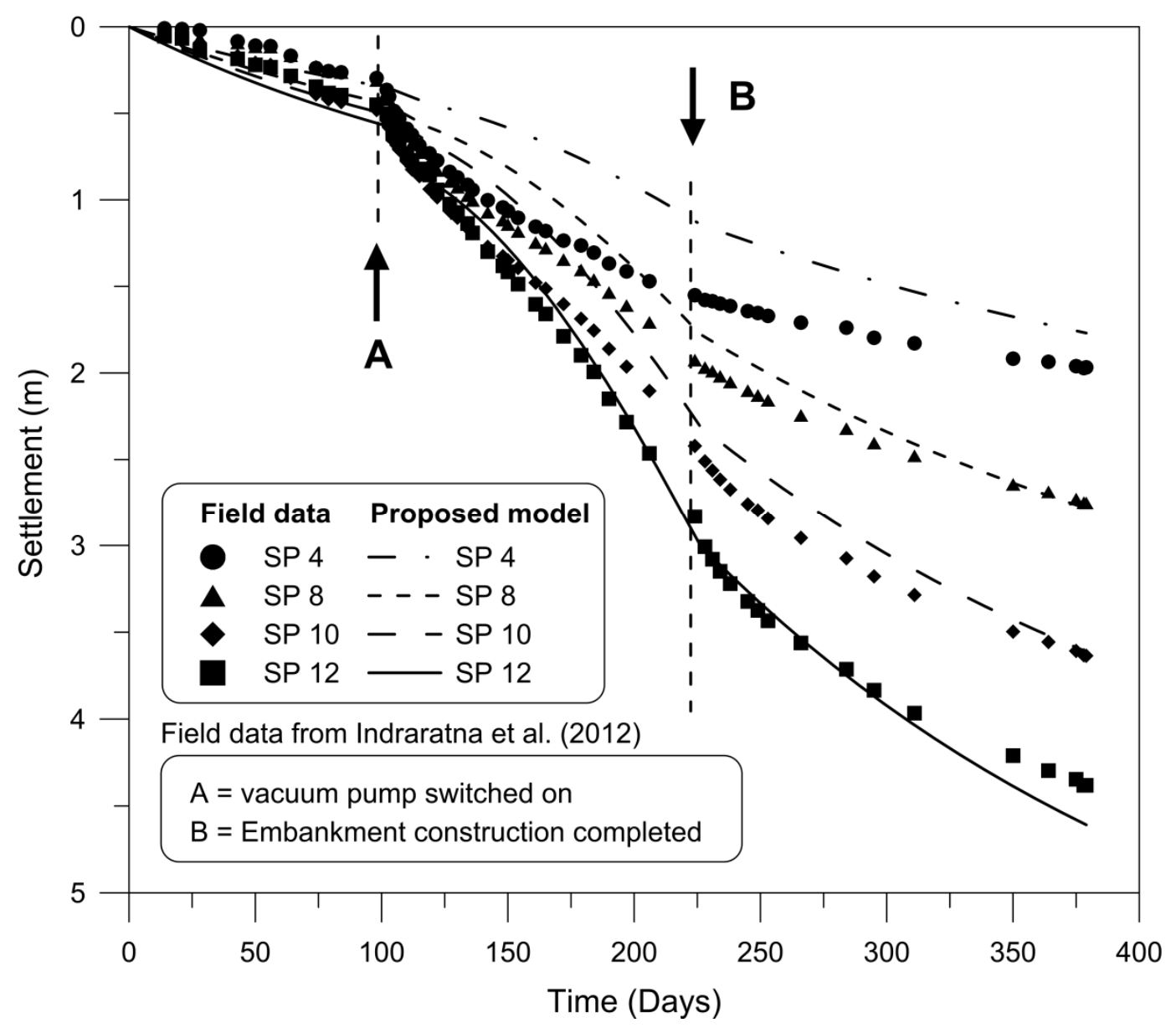

Figure 10 : Surface settlement prediction at different settlement plates 




Figure 11 : Settlement at SP12 compared to other analytical methods by Indraratna et al. (2005a) and Hansbo (1981) 


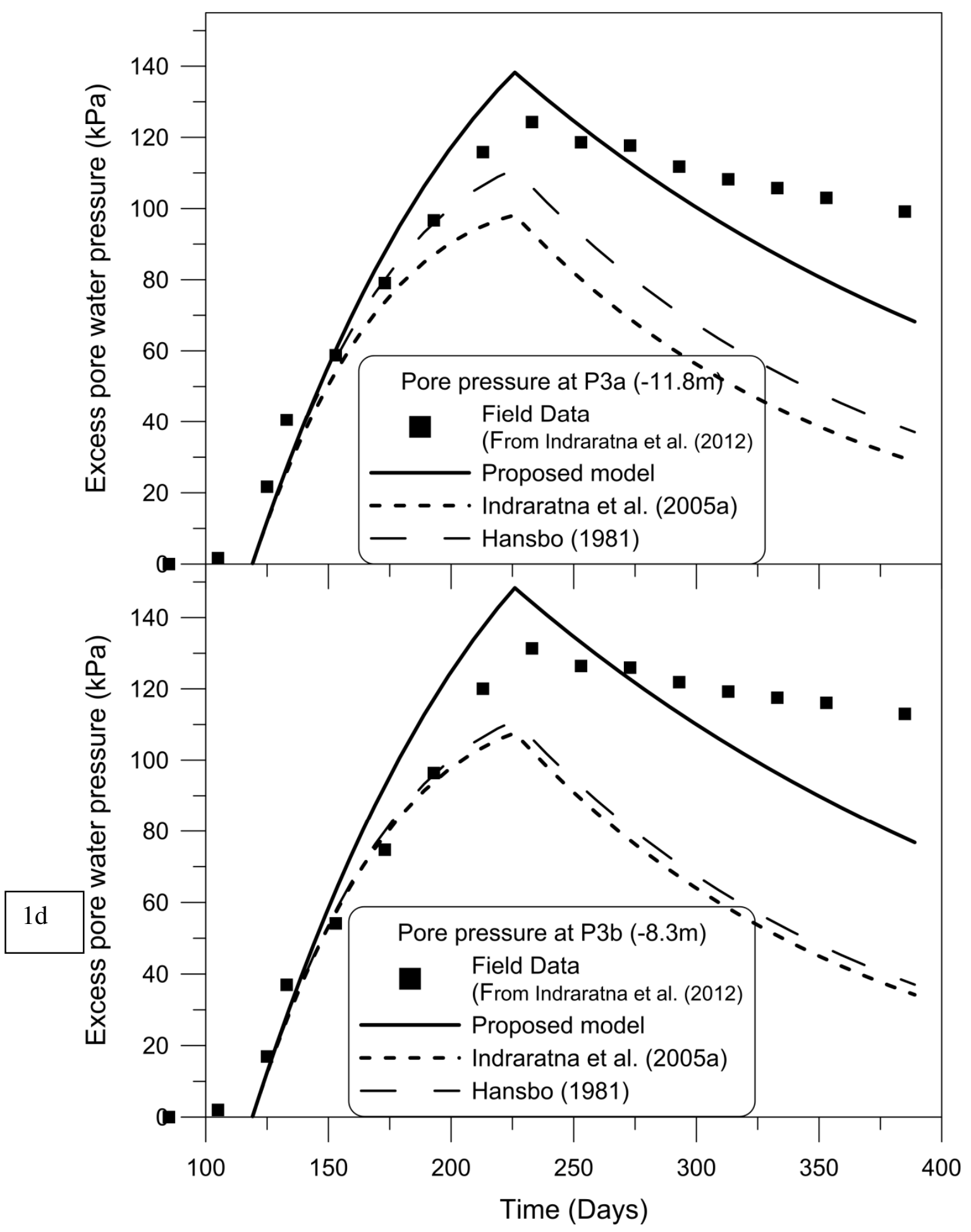

Figure 12 : Observed and predicted distributions of excess pore water pressure by the current method, Indraratna et al. (2005a) and Hansbo (1981) for a) P2a (8.3m below the ground surface) and b) P2b (4.8m below the ground surface) 


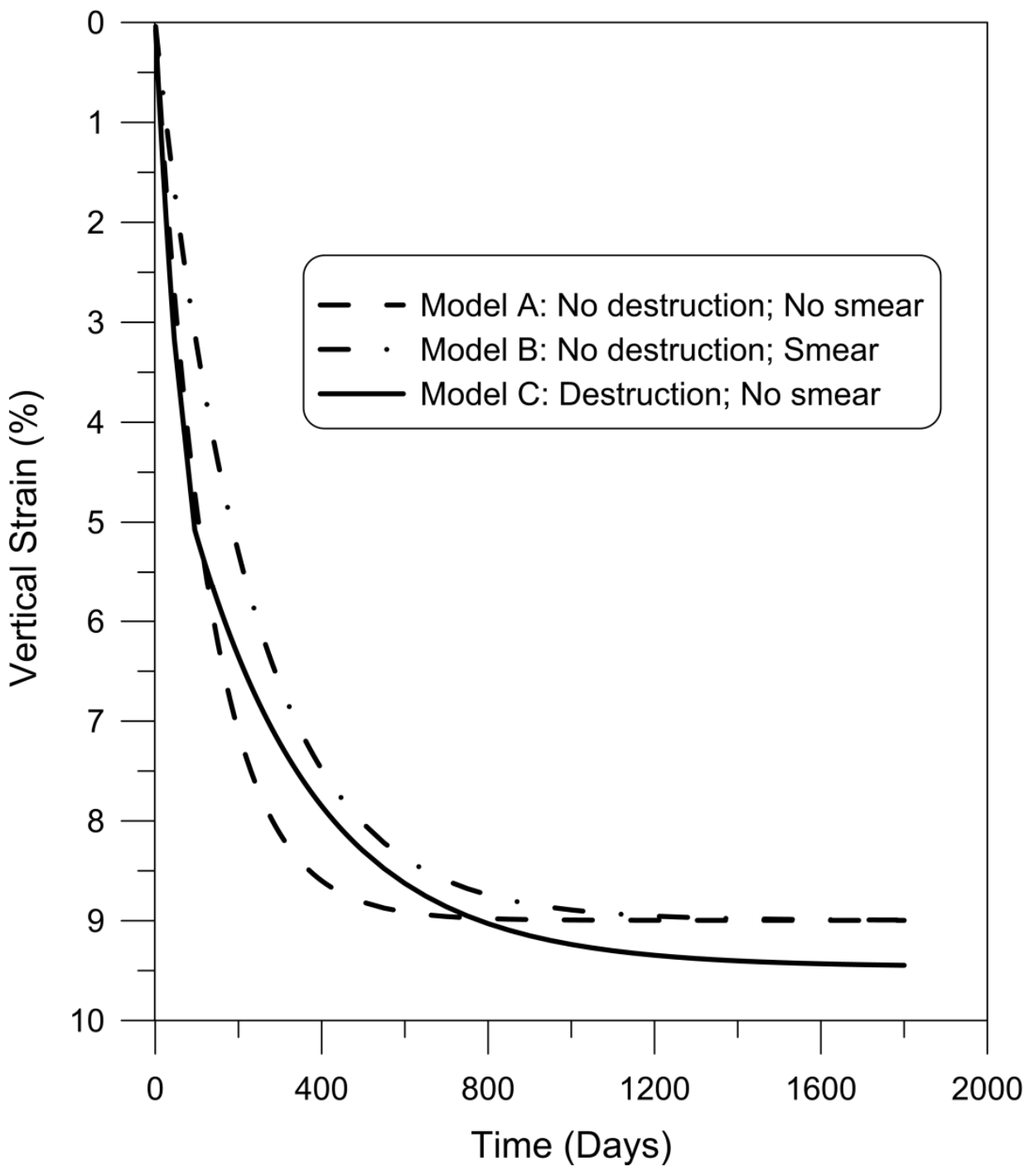

Figure 13 : Effects of reduced permeability and destructuration in smear zone on time-settlement curves 


\section{TABLES}

Table 1 : Drain parameters used for parametric analysis.(From Indraratna et al 2015)

$1 \mathrm{c}$

\begin{tabular}{|l|c|}
\hline \multicolumn{1}{|c|}{ Parameter } & Value \\
\hline $\begin{array}{l}\boldsymbol{r}_{\boldsymbol{w}}(\mathrm{mm})^{*} \text { *based on } \\
\text { Rixner et al.(1986) }\end{array}$ & 25.75 \\
\hline $\boldsymbol{r}_{\boldsymbol{s}}(\mathrm{mm})$ & 400 \\
\hline $\boldsymbol{d}_{\boldsymbol{e}}(\mathrm{mm})$ & 1356 \\
\hline $\boldsymbol{s}$ & 15.53 \\
\hline $\boldsymbol{n}$ & 26.3 \\
\hline
\end{tabular}


Table 2: Soil parameters used in the sensitivity analysis of normally consolidated clay

\begin{tabular}{|c|c|c|c|c|c|c|c|c|c|}
\hline \multirow{2}{*}{ Soil Parameters } & \multicolumn{3}{|c|}{ Current Model } & \multicolumn{3}{|c|}{$\begin{array}{c}\text { Indraratna et al. } \\
(\text { 2005a) }\end{array}$} & \multicolumn{3}{|c|}{ Hansbo (1981) } \\
\hline & $\begin{array}{c}\text { Case } \\
\text { A }\end{array}$ & $\begin{array}{c}\text { Case } \\
\text { B }\end{array}$ & $\begin{array}{c}\text { Case } \\
\text { C }\end{array}$ & $\begin{array}{c}\text { Case } \\
\text { A }\end{array}$ & $\begin{array}{c}\text { Case } \\
\text { B }\end{array}$ & $\begin{array}{c}\text { Case } \\
\text { C }\end{array}$ & $\begin{array}{c}\text { Case } \\
\text { A }\end{array}$ & $\begin{array}{c}\text { Case } \\
\text { B }\end{array}$ & $\begin{array}{c}\text { Case } \\
\text { C }\end{array}$ \\
\hline $\boldsymbol{\sigma}_{\mathbf{0}}^{\prime}(k P a)$ & 28.0 & 28.0 & 28.0 & 28.0 & 28.0 & 28.0 & 28.0 & 28.0 & 28.0 \\
\hline $\boldsymbol{\sigma}_{\boldsymbol{f}}^{\prime}(k P a)$ & 68.0 & 108.0 & 148.0 & 68.0 & 108.0 & 148.0 & 68.0 & 108.0 & 148.0 \\
\hline $\boldsymbol{u}_{\mathbf{0}}(k P a)$ & 20.0 & 40.0 & 60.0 & 20.0 & 40.0 & 60.0 & 20.0 & 40.0 & 60.0 \\
\hline $\boldsymbol{p}_{\mathbf{0}}(k P a)$ & 20.0 & 40.0 & 60.0 & 20.0 & 40.0 & 60.0 & 20.0 & 40.0 & 60.0 \\
\hline$\overline{\boldsymbol{e}}_{\mathbf{0}}, \boldsymbol{e}_{\boldsymbol{o}, U}$ & 1.949 & 1.949 & 1.949 & 2.112 & 2.112 & 2.112 & 2.112 & 2.112 & 2.112 \\
\hline$\overline{\boldsymbol{e}}_{\boldsymbol{f}}, \boldsymbol{e}_{\boldsymbol{f}, U}$ & 1.653 & 1.509 & 1.415 & 1.783 & 1.625 & 1.522 & 1.783 & 1.625 & 1.522 \\
\hline$f_{0}$ & 1.38 & 1.38 & 1.38 & N/A & N/A & N/A & N/A & N/A & N/A \\
\hline $\boldsymbol{f}_{f}$ & 1.35 & 1.35 & 1.34 & N/A & N/A & N/A & N/A & N/A & N/A \\
\hline$\overline{\boldsymbol{c}}_{\boldsymbol{c}}, \boldsymbol{c}_{\boldsymbol{c}}$ & 0.77 & 0.75 & 0.74 & 0.85 & 0.83 & 0.82 & 0.85 & 0.83 & 0.82 \\
\hline$c_{k}$ & 0.65 & 0.65 & 0.65 & 0.65 & 0.65 & 0.65 & 0.65 & 0.65 & 0.65 \\
\hline$P_{a v, 0}$ & 1.038 & 1.076 & 1.110 & 0.991 & 1.009 & 1.030 & N/A & N/A & N/A \\
\hline $\begin{array}{l}\boldsymbol{k}_{\boldsymbol{h 0}}, \boldsymbol{k}_{\boldsymbol{o}, \boldsymbol{U}} \\
\times \mathbf{1 0}^{-10}(\mathrm{~m} / \mathrm{s})\end{array}$ & 4.35 & 4.35 & 4.35 & 6.79 & 6.79 & 6.79 & 6.79 & 6.79 & 6.79 \\
\hline $\boldsymbol{k}\left(\boldsymbol{r}_{\boldsymbol{w}}\right)_{\mathbf{0}} \times 10^{-10}(\mathrm{~m} / \mathrm{s})$ & 1.37 & 1.37 & 1.37 & N/A & N/A & N/A & N/A & N/A & N/A \\
\hline $\boldsymbol{k}_{\boldsymbol{h}} / \boldsymbol{k}_{\boldsymbol{h}}^{\prime} \times \mathbf{1 0}^{-\mathbf{1 0}}(\mathrm{m} / \mathrm{s})$ & N/A & N/A & N/A & 1.67 & 1.67 & 1.67 & 1.67 & 1.67 & 1.67 \\
\hline $\boldsymbol{k}_{\boldsymbol{h}(\boldsymbol{a v g})} \times \mathbf{1 0}^{-10}(\mathrm{~m} / \mathrm{s})$ & N/A & N/A & N/A & 5.17 & 4.11 & 3.53 & 5.17 & 4.11 & 3.53 \\
\hline $\begin{array}{l}\boldsymbol{m}_{\boldsymbol{v}(\boldsymbol{a v g})} \\
\times \mathbf{1 0}^{-3}\left(\mathrm{~m}^{2} / k N\right)\end{array}$ & 2.52 & 1.87 & 1.51 & 2.64 & 1.96 & 1.58 & 2.64 & 1.96 & 1.58 \\
\hline $\boldsymbol{\kappa}$ & 3.182 & 3.182 & 3.182 & N/A & N/A & N/A & N/A & N/A & N/A \\
\hline $\boldsymbol{\mu}$ & 3.969 & 3.969 & 3.969 & 3.195 & 3.195 & 3.195 & 3.195 & 3.195 & 3.195 \\
\hline
\end{tabular}


Table 3: Soil parameters used in the sensitivity analysis of over-consolidated clay

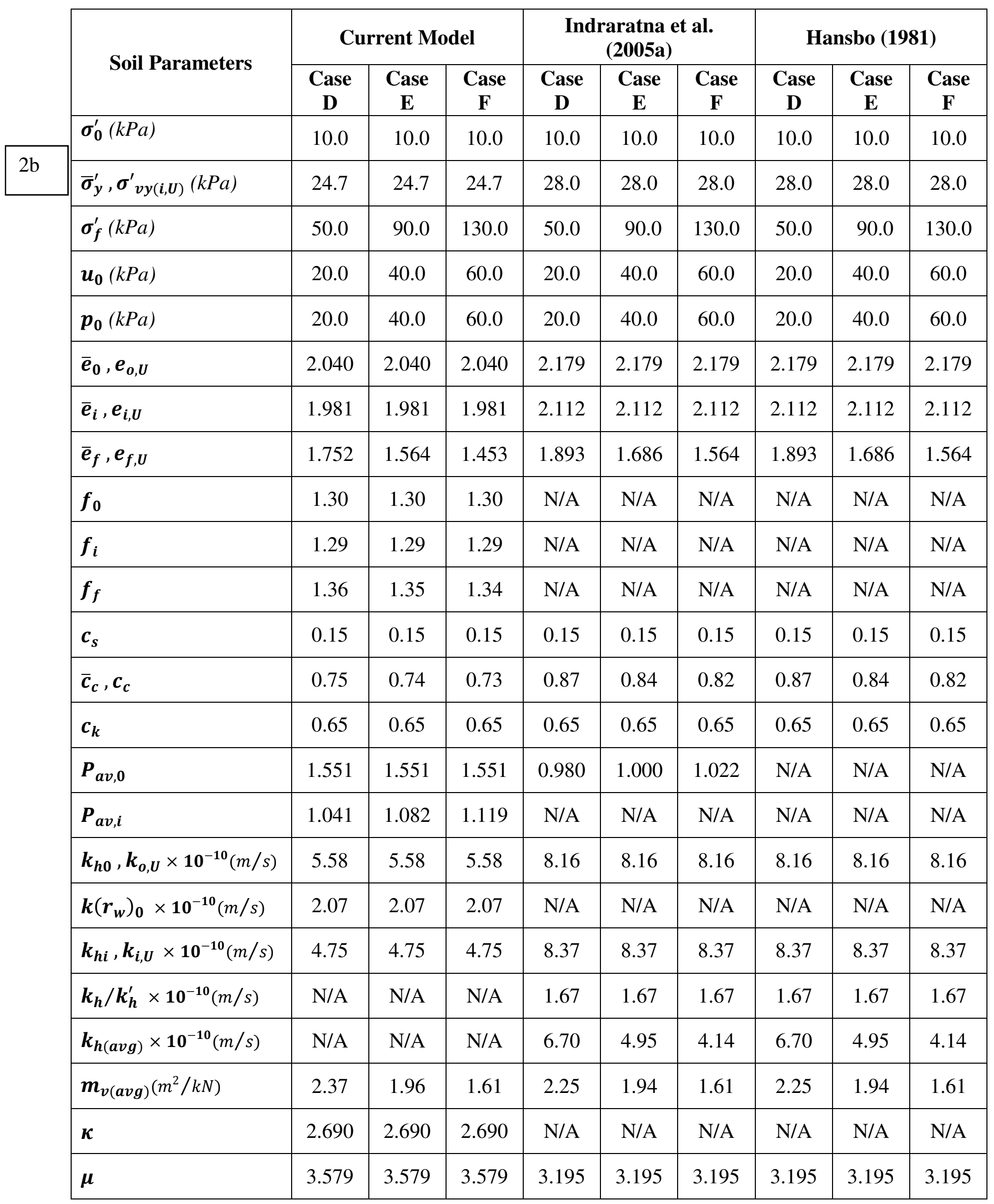


Table 4 : Bottom level of soft soil beneath each settlement plate

\begin{tabular}{|c|c|c|c|c|c|c|}
\hline $\begin{array}{c}\text { Settlement } \\
\text { Plate }\end{array}$ & $\begin{array}{c}\text { SP 1 } \\
\text { SP 2 }\end{array}$ & $\begin{array}{c}\text { SP 3 } \\
\text { SP 4 }\end{array}$ & $\begin{array}{c}\text { SP 5 } \\
\text { SP 6 }\end{array}$ & $\begin{array}{c}\text { SP 7 } \\
\text { SP 8 }\end{array}$ & $\begin{array}{c}\text { SP 9 } \\
\text { SP 10 }\end{array}$ & $\begin{array}{c}\text { SP 11 } \\
\text { SP 12 }\end{array}$ \\
\hline $\begin{array}{c}\text { Bottom level } \\
(\mathrm{m})\end{array}$ & $2.7-6.7$ & $6.7-9.7$ & $9.7-11.7$ & $11.7-14.7$ & $14.7-17.7$ & $17.7-24.7$ \\
\hline
\end{tabular}

Table 5: Properties of vertical drain and other parameters used in case study analysis.

\begin{tabular}{|c|c|c|c|c|c|c|c|c|}
\hline Parameter & $\begin{array}{c}\boldsymbol{r}_{w} \\
(\mathbf{m m})\end{array}$ & $\begin{array}{c}\boldsymbol{r}_{\boldsymbol{s}} \\
(\mathbf{m m})\end{array}$ & $\begin{array}{c}\boldsymbol{d}_{\boldsymbol{e}} \\
(\mathbf{m m})\end{array}$ & $\boldsymbol{s}$ & $\boldsymbol{n}$ & $\boldsymbol{f}_{\boldsymbol{0}}$ & $\boldsymbol{f}_{\boldsymbol{i}}$ & $\boldsymbol{f}_{\boldsymbol{f}}$ \\
\hline Value & 17 & 300 & 1130 & 17.65 & 33.24 & 1.38 & 1.38 & 1.35 \\
\hline
\end{tabular}

Table 6 : Soil parameters used in the analysis at SP12

\begin{tabular}{|c|c|c|c|c|c|c|c|}
\hline Depth (m) & $\boldsymbol{C}_{\boldsymbol{c}}$ & $\boldsymbol{C}_{\boldsymbol{r}}$ & $\begin{array}{c}\boldsymbol{\gamma} \\
\left(\boldsymbol{k N} / \mathbf{m}^{3}\right)\end{array}$ & $\boldsymbol{e}_{\boldsymbol{0}}$ & $\begin{array}{c}\boldsymbol{k}_{\boldsymbol{h}} \\
(\mathrm{m} / \mathrm{s})\end{array}$ & OCR & $\boldsymbol{c}_{\boldsymbol{k}}$ \\
\hline $\mathbf{0 . 0 - 4 . 4}$ & 1.31 & 0.23 & 14.5 & 2.90 & $10 \times 10^{-10}$ & 3.0 & 1.45 \\
\hline $\mathbf{4 . 4 - 1 1 . 5}$ & 1.54 & 0.60 & 13.7 & 3.25 & $10 \times 10^{-10}$ & 1.2 & 1.63 \\
\hline $\mathbf{1 1 . 5 - 1 9 . 0}$ & 1.45 & 0.21 & 14.2 & 2.90 & $10 \times 10^{-10}$ & 1.2 & 1.45 \\
\hline $\mathbf{1 9 . 0 - 2 5 . 0}$ & 0.85 & 0.21 & 15.8 & 2.60 & $3.3 \times 10^{-10}$ & 1.1 & 1.30 \\
\hline
\end{tabular}




\section{FIGURES}

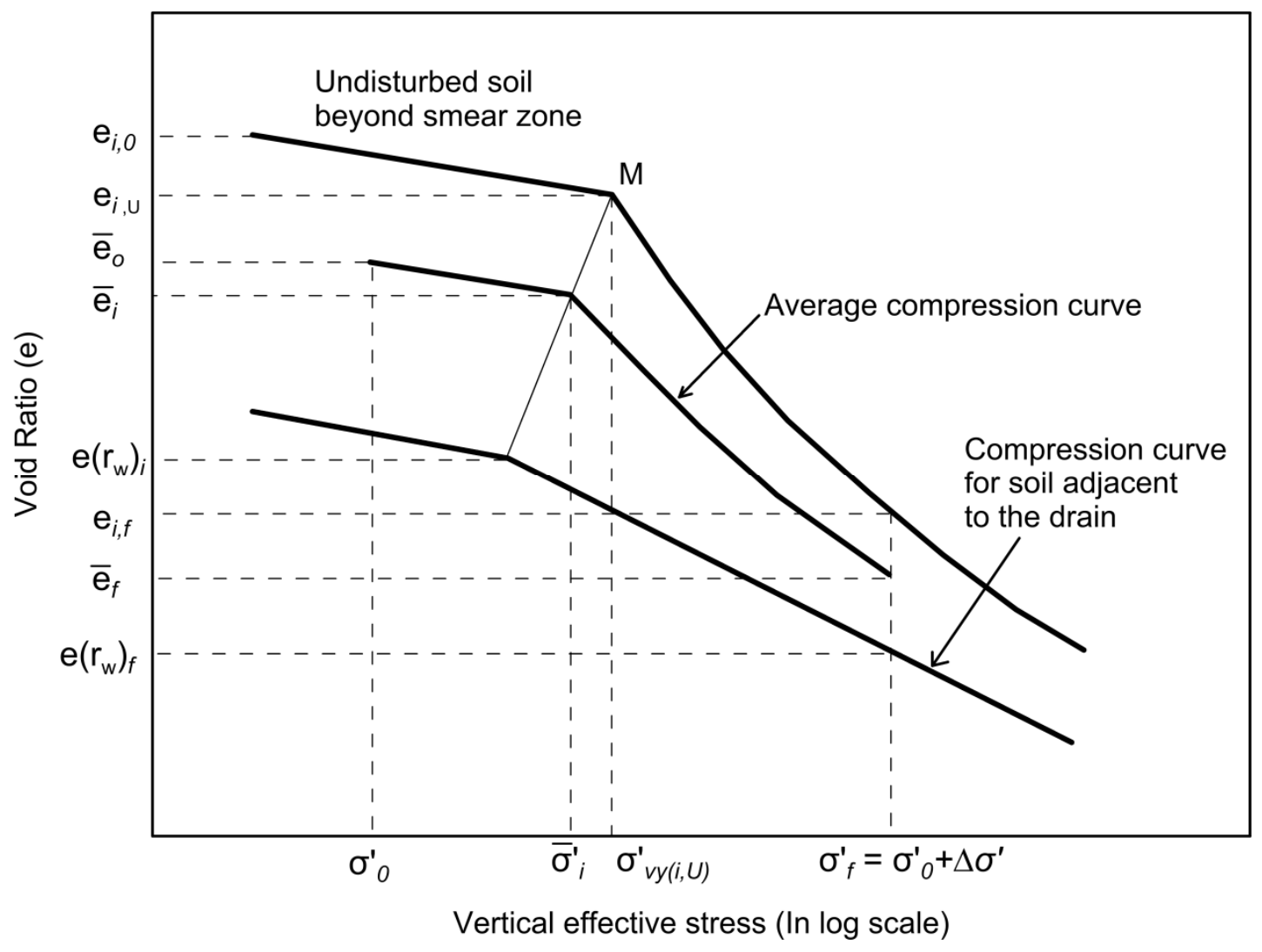

Figure 1 : Compression curves for in-situ and disturbed soil. 


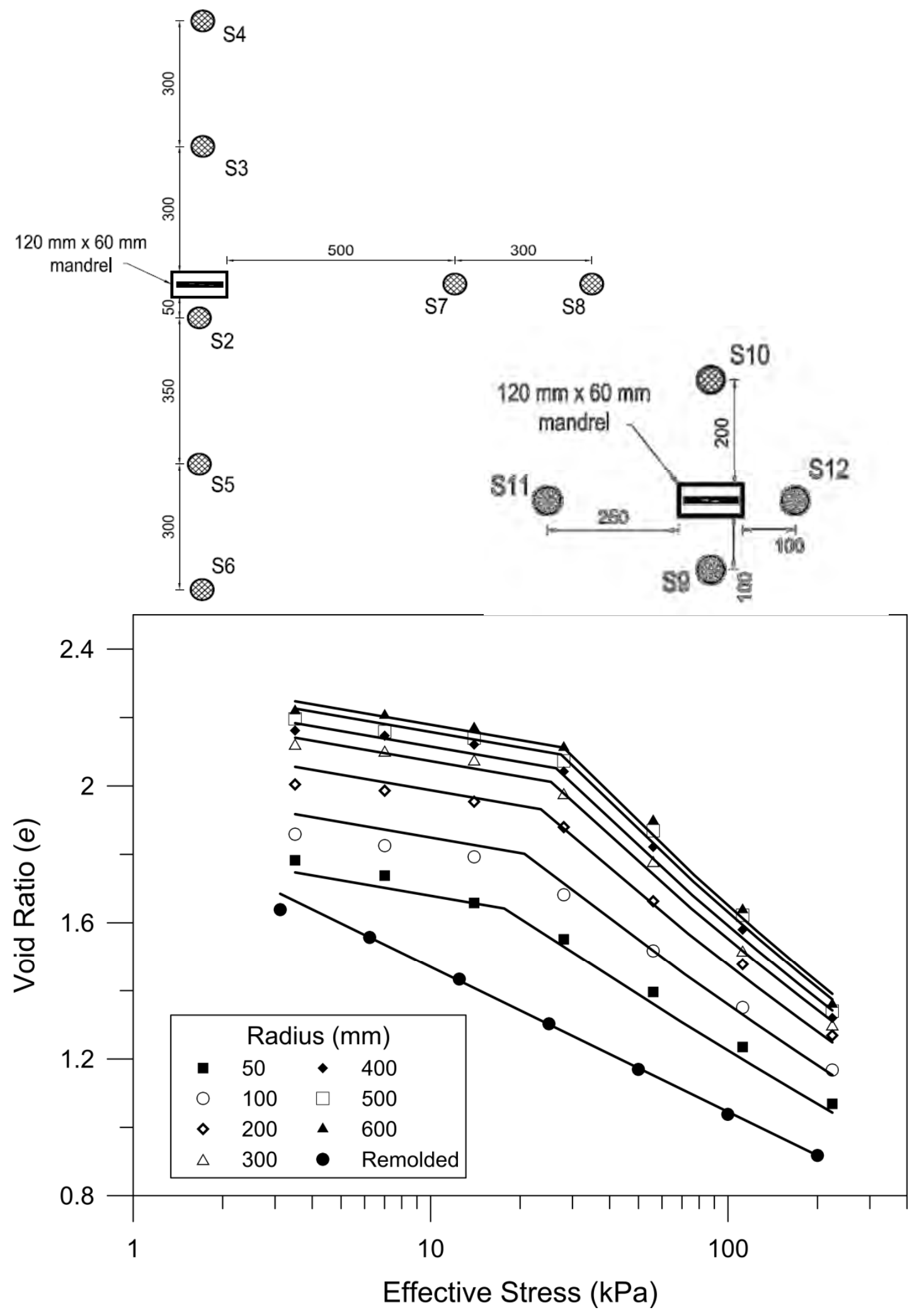

Figure $2:$ a) Sampling locations and the b) Compression curves based on oedometer test 




Figure 3: Vacuum pressure distribution in an axisymmetric unit cell 




Figure 4 : a) Averaged compression curves; b) Variation of permeability with the void ratio based on oedometer tests 

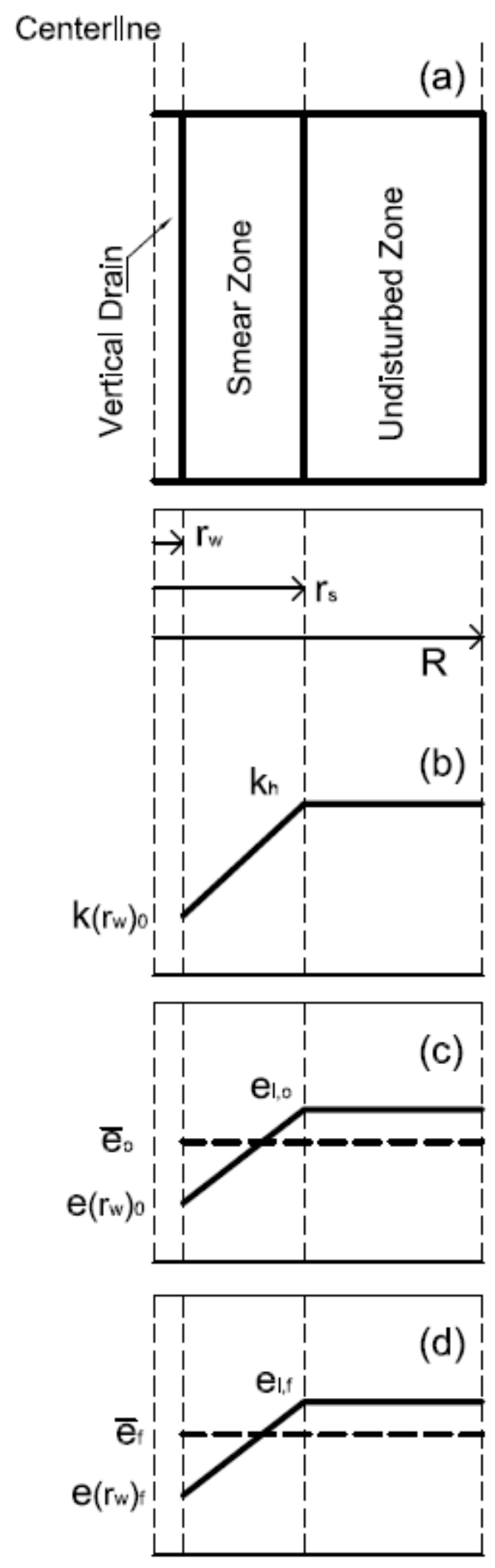

Figure 5 : Variation of b) Permeability; c) initial void ratio; d) final void ratio of a unit cell with a vertical drain (Modified after Rujikiatkamjorn \& Indraratna 2014) 

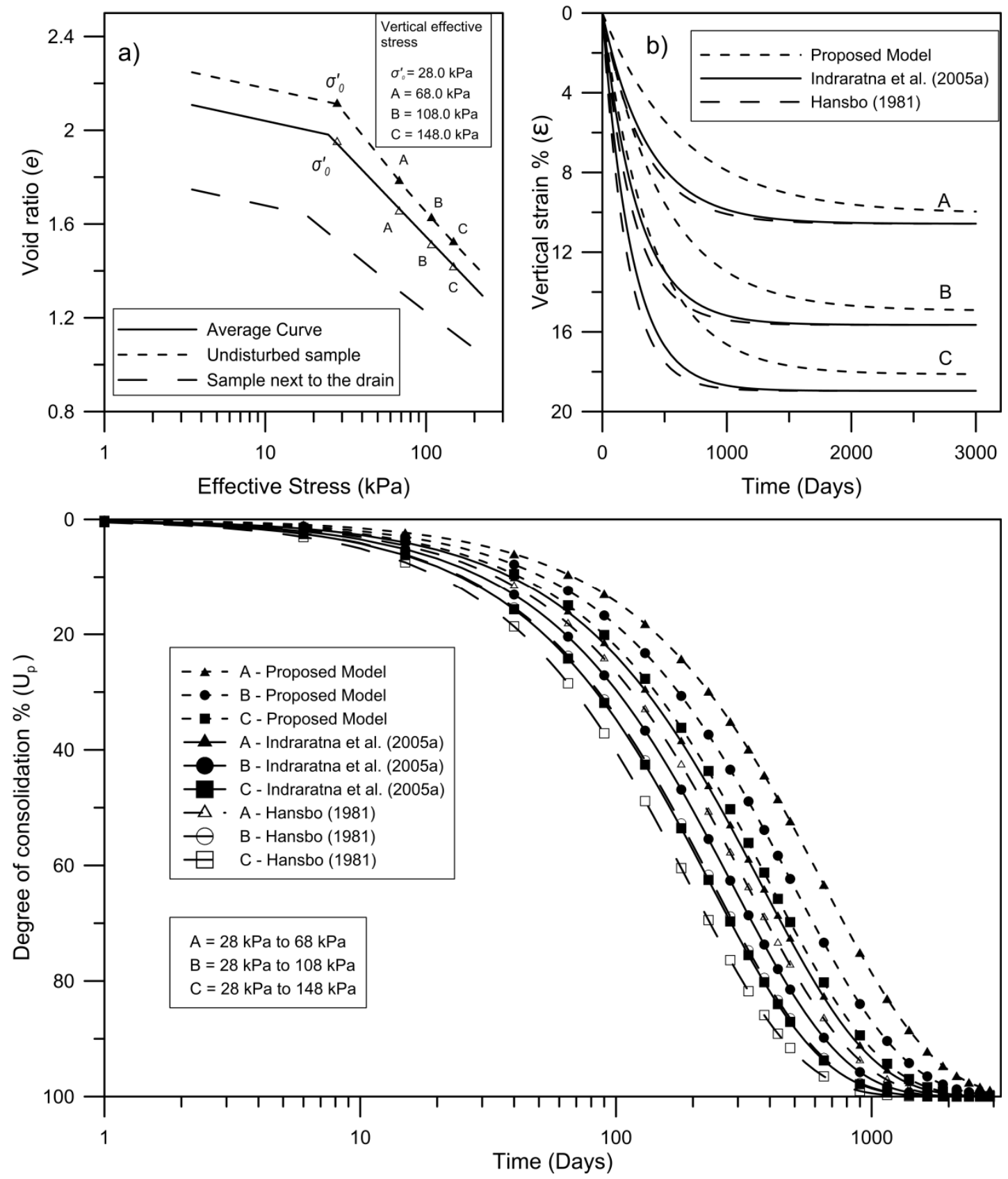

Figure 6 : Predicted model response of normally consolidated clay, compared to Indraratna et al. (2005a) and Hansbo (1981): (a) the relationship between the Void ratio and effective stress, and (b) vertical strain with time, and (c) the degree of consolidation with time 

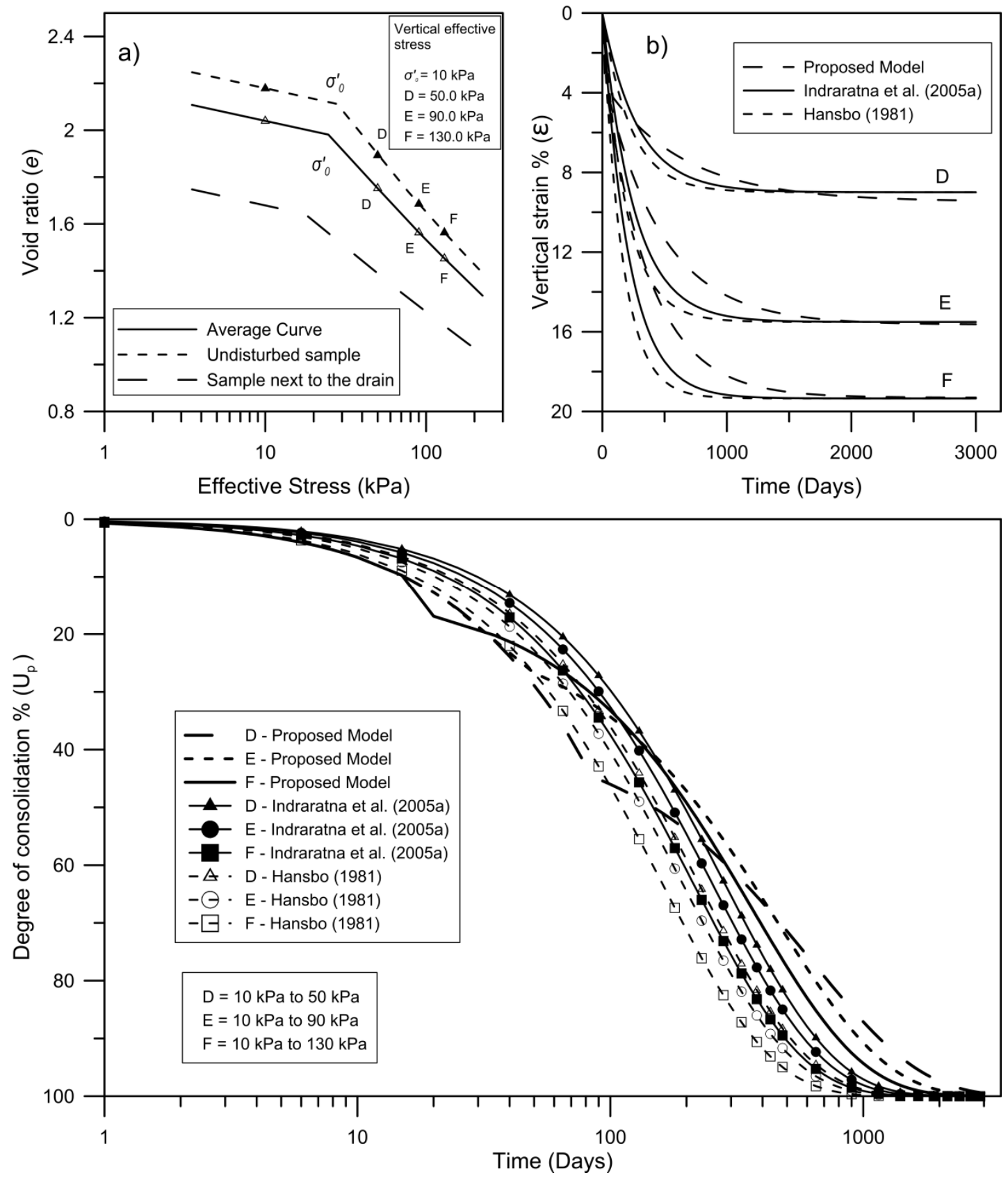

Figure 7 : Consolidation of lightly over-consolidated clay by the predicted model compared to Indraratna et al. (2005a) and Hansbo (1981) showing: (a) the relationship between the Void ratio and effective stress, (b) the vertical strain with time, and (c) the degree of consolidation with time 


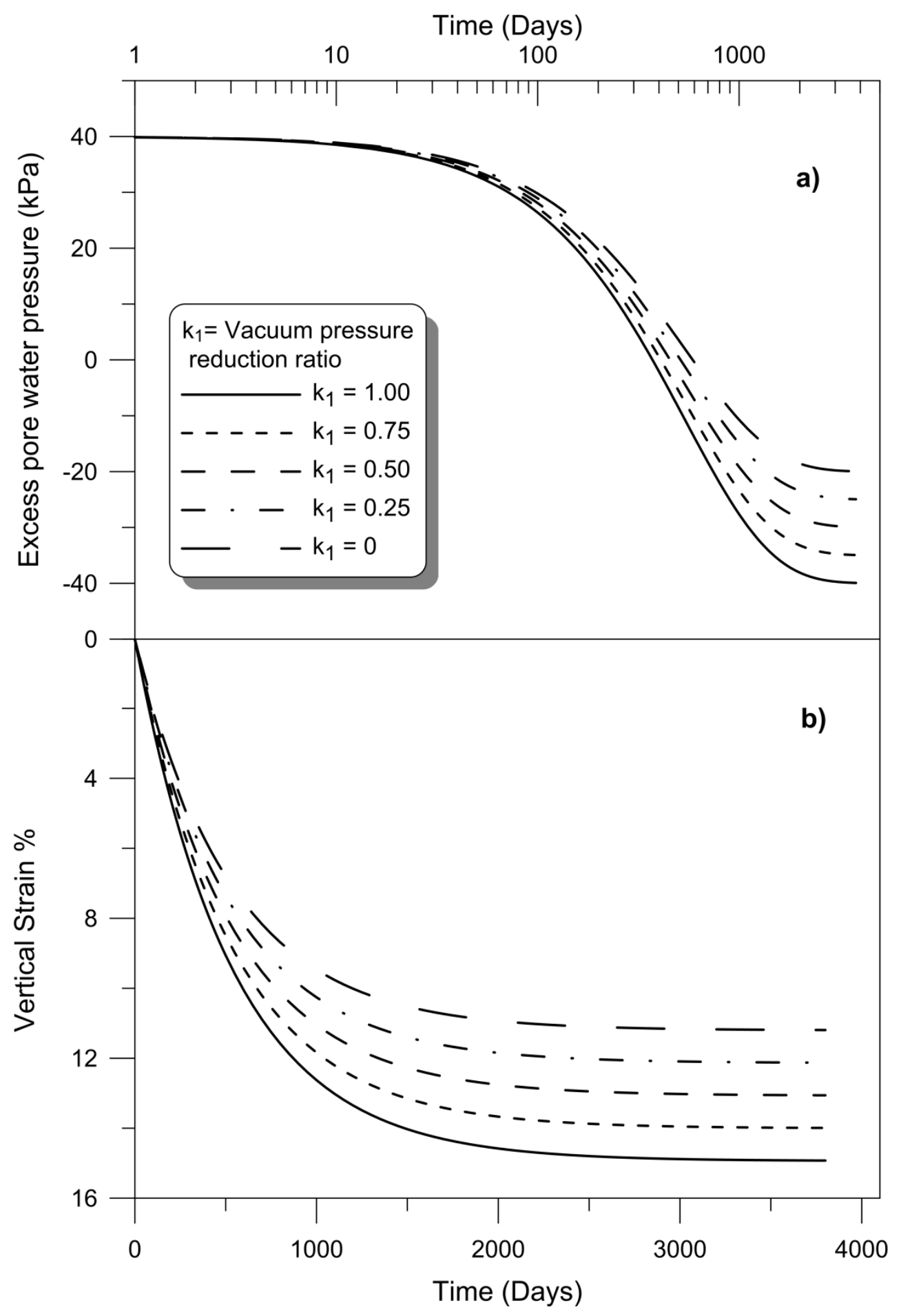

Figure 8 : Effects of vacuum distribution along the drain for normally consolidated clay: a) Excess pore water pressure; b) Vertical strain 


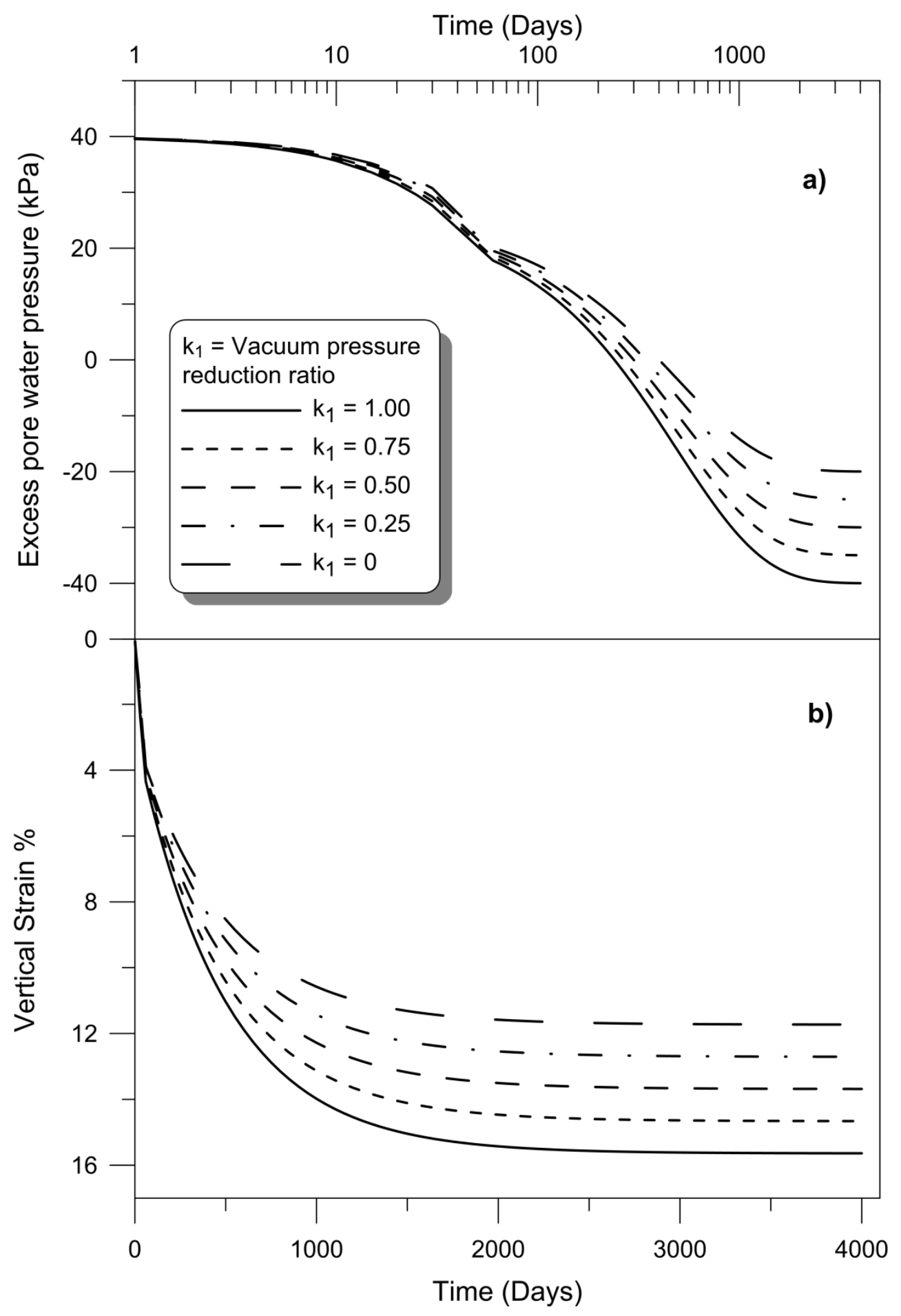

Figure 9 : Effects of vacuum distribution inside the drain on the consolidation parameters in lightly over consolidated clay: a) Excess pore water pressure; b) Vertical strain 




Figure 10 : Surface settlement prediction at different settlement plates 




Figure 11 : Settlement at SP12 compared to other analytical methods by Indraratna et al. (2005a) and Hansbo (1981) 


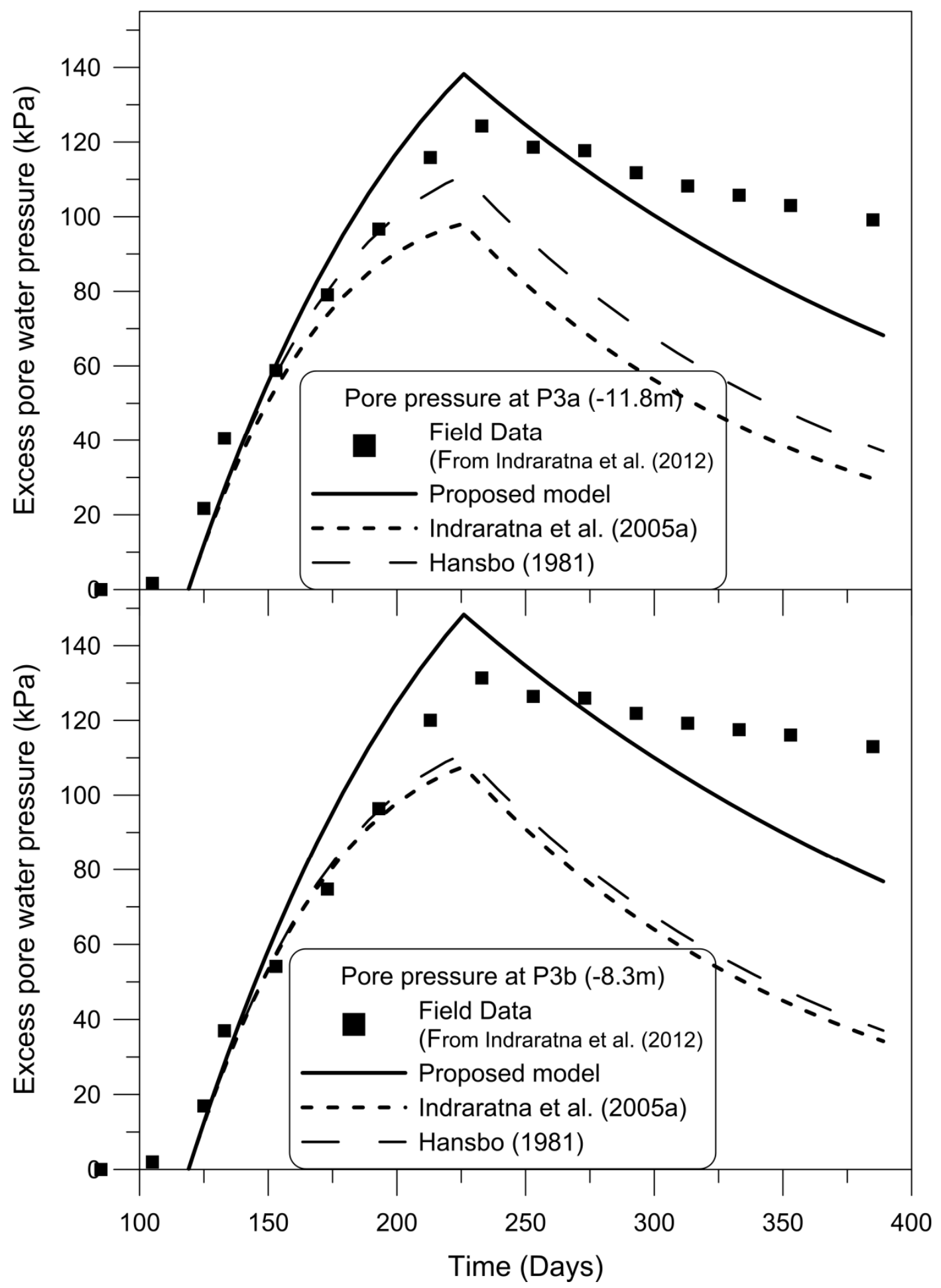

Figure 12 : Observed and predicted distributions of excess pore water pressure by the current method, Indraratna et al. (2005a) and Hansbo (1981) for a) P2a (8.3m below the ground surface) and b) P2b (4.8m below the ground surface) 


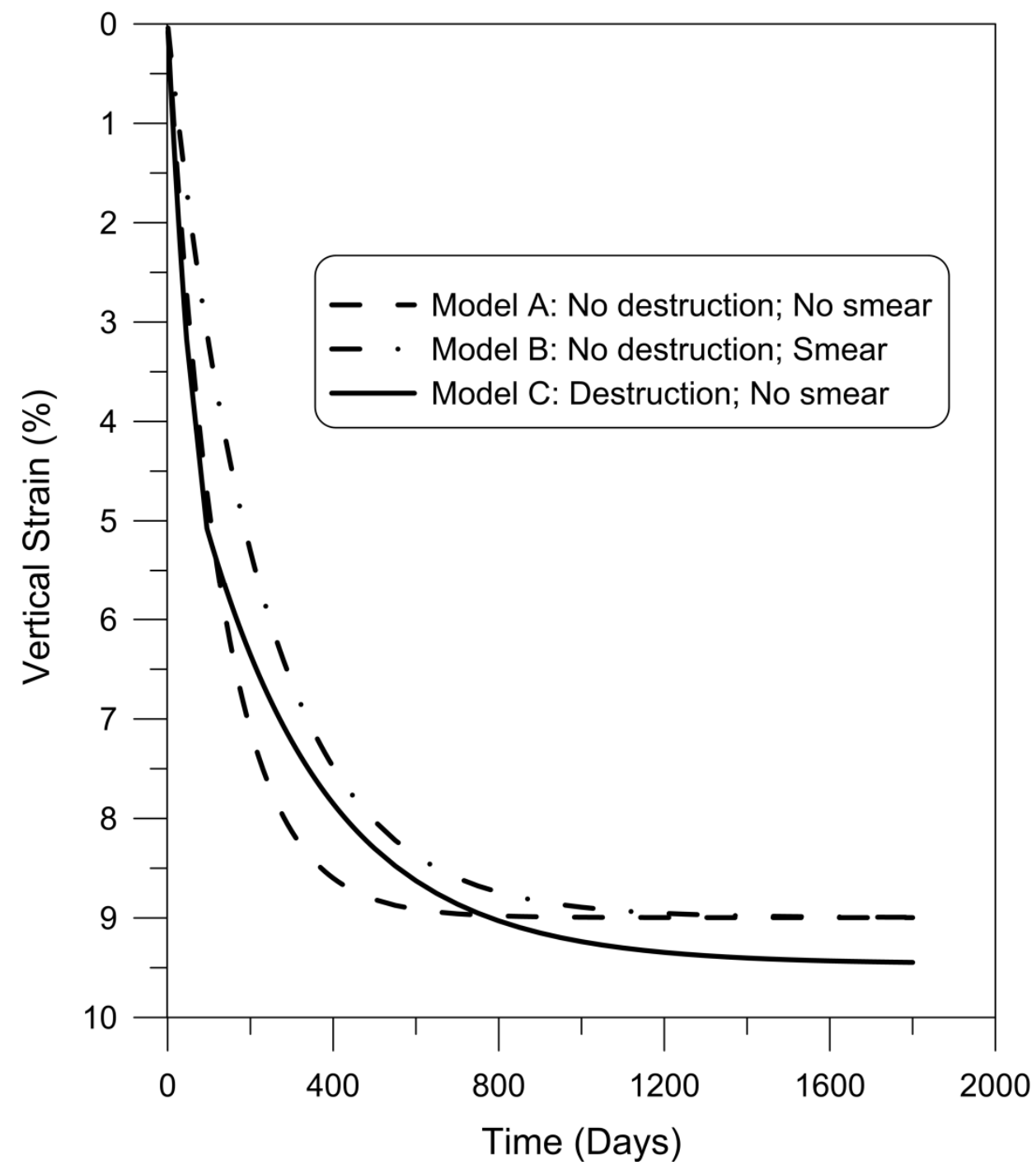

Figure 13 : Effects of reduced permeability and destructuration in smear zone on time-settlement curves 